\title{
The Role of Supplementary Cementitious Materials (SCMs) in Ultra High Performance Concrete (UHPC): A Review
}

\author{
Sungwoo Park ${ }^{1,+}$ (D) Siyu Wu ${ }^{1,+}$, Zhichao Liu ${ }^{2,3}$ and Sukhoon Pyo ${ }^{1, *(1)}$ \\ 1 Department of Urban and Environmental Engineering, Ulsan National Institute of Science and \\ Technology (UNIST), Ulsan 44919, Korea; paksungwoo@unist.ac.kr (S.P.); wsy86023@unist.ac.kr (S.W.) \\ 2 State Key Laboratory of Silicate Materials for Architectures, Wuhan University of Technology, \\ Wuhan 430070, China; liuzc9@whut.edu.cn \\ 3 School of Materials Science and Engineering, Wuhan University of Technology, Wuhan 430070, China \\ * Correspondence: shpyo@unist.ac.kr \\ + These authors contributed equally to the present study.
}

Citation: Park, S.; Wu, S.; Liu, Z.; Pyo, S. The Role of Supplementary Cementitious Materials (SCMs) in Ultra High Performance Concrete (UHPC): A Review. Materials 2021, 14, 1472. https://doi.org/10.3390/ ma14061472

Academic Editor: Angelo

Marcello Tarantino

Received: 8 February 2021

Accepted: 10 March 2021

Published: 17 March 2021

Publisher's Note: MDPI stays neutral with regard to jurisdictional claims in published maps and institutional affiliations.

Copyright: (c) 2021 by the authors. Licensee MDPI, Basel, Switzerland. This article is an open access article distributed under the terms and conditions of the Creative Commons Attribution (CC BY) license (https:// creativecommons.org/licenses/by/ $4.0 /)$.

\begin{abstract}
Although ultra high-performance concrete (UHPC) has great performance in strength and durability, it has a disadvantage in the environmental aspect; it contains a large amount of cement that is responsible for a high amount of $\mathrm{CO}_{2}$ emissions from UHPC. Supplementary cementitious materials (SCMs), industrial by-products or naturally occurring materials can help relieve the environmental burden by reducing the amount of cement in UHPC. This paper reviews the effect of SCMs on the properties of UHPC in the aspects of material properties and environmental impacts. It was found that various kinds of SCMs have been used in UHPC in the literature and they can be classified as slag, fly ash, limestone powder, metakaolin, and others. The effects of each SCM are discussed mainly on the early age compressive strength, the late age compressive strength, the workability, and the shrinkage of UHPC. It can be concluded that various forms of SCMs were successfully applied to UHPC possessing the material requirement of UHPC such as compressive strength. Finally, the analysis on the environmental impact of the UHPC mix designs with the SCMs is provided using embodied $\mathrm{CO}_{2}$ generated during the material production.
\end{abstract}

Keywords: ultra high-performance concrete (UHPC); supplementary cementitious materials (SCMs); sustainability; compressive strength; flowability; shrinkage

\section{Introduction}

Ultra high-performance concrete (UHPC) is one of the leading construction materials with greatly advanced properties compared to conventional concrete. A cementitious mixture of which the compressive strength is over 120 MPa belongs to the UHPC category according to ASTM C1856 [1], while the ACI committee reported that the compressive strength of UHPC should be greater than $150 \mathrm{MPa}$ [2-4]. In addition to the remarkable compressive strength, UHPC, designed based on a particle packing theory, also possesses superior durability compared to conventional concrete with the help of dense microstructure [5-15]. For example, it has strong resistance to water permeability, chloride penetration, freeze and thaw, and chemical attack because of its great material properties. Comprehensive studies on UHPC have been conducted for the last few decades such as the rheological properties of a fresh paste of UHPC [15-20], the effect of fibers [16,19,21-23], mix design [24-29], and structural applications [30-33].

Perhaps, the disadvantage of UHPC comes from the standard ingredient, specifically, a large portion of Portland cement. The cement industry is well known to generate $8-9 \%$ of global $\mathrm{CO}_{2}$ emissions [34]. Even though the structure member size can be smaller with UHPC than conventional concrete because of its high strength [35], UHPC generally contains cement about three times higher than normal concrete by volume [25,36]. Furthermore, not all cement particles in UHPC are hydrated in an extremely low w/c 
ratio environment. The hydration degree is reported as only $52-61 \%$ with a $\mathrm{w} / \mathrm{c}$ ratio of $0.23-0.33$ [37] and the unhydrated cement makes UHPC not eco-friendly [12,38]. Therefore, the possible approach to reduce cement content in UHPC is replacing part of the cement with supplementary cementitious materials (SCMs) such as slag, fly ash (FA), limestone powder (LP), metakaolin (MK), and other SCMs. Most SCMs are industrial by-products or naturally occurring materials: slags are by-products in the production of iron, steel, lithium carbonate, phosphor, or copper; FA is a by-product of a coal power plant; and SF is a by-product from the production of elemental silicon or alloys with silicon. In addition, limestone is a natural occurring material, and $\mathrm{MK}$ is obtained from the calcination of kaolinite.

This paper reviewed the effect of various SCMs on UHPC performances. SCMs can be categorized into slag, FA, LP, MK, and other SCMs. The effects of SCMs on compressive strength, flowability, porosity, shrinkage, and environmental impacts of UHPC are discussed. The paper also introduces the method of how to evaluate the environmental effect of each SCM. The objective of the paper is to summarize the current state of SCM application and its performances in UHPC.

\section{Summary of SCMs Reviewed}

The SCMs reviewed in this paper are summarized in Table 1. The table shows the types of SCMs that have been studied in the literature and their effects on the UHPC's performances. The performances of UHPC investigated are early (at 3 days or earlier) and late compressive strength (later than 3 days), flowability, porosity, and shrinkage. The effects of SCMs were compared to the references in each study. For example, high "Early compressive strength" means that usage of SCMs exhibits higher early compressive strength than a reference mix design. The numbers in the column of "SMC No." are linked to the numbers in the column of "List of SCMs" and the information of SCMs or a combination of SCMs can be found.

When a combination of SCMs is used, the effects of the main SCM are reported. Many studies investigated the usage of combinations of SCMs and it is inefficient to regard each combination as a single different SCM. Therefore, the authors picked one representative SCM in a combination and investigated its effect. The representative SCM in a combination is bolded in the table and others are referred to as a reference. For example, (8) in the "List of SCMs" column in Table 1 used three SCMs: GGBS (25.5\%) + SF + BA. The compressive strength with the different dosages of GGBS was compared and discussed in the slag section (see Section 3.1). The UHPC with GGBS exhibits lower early age compressive strength compared to the reference with the combination of SF and BA only. In the case of italic texts for the SCMs, the reference is different from the mix designs with SCMs and is not able to be written in the Table 1 because of space limitations. For example, (22) in the "List of SCMs" column in Table 1 compared the effect of "FFA (20\%) + MK (3.8\%)" with the UHPC only with SF. In this case, it is recommended to find more detailed information on the reference mix design through the papers cited. Lastly, the replacement ratio is the weight of the SCM to total solid binder weight, which resulted in the highest compressive strength. For example, (8) in the "List of SCMs" column in Table 1 GGBS is used along with BA and SF. The replacement ratio of $25.5 \%$ is obtained from dividing GBBS weight by the sum of cement, GBBS, BA, and SF.

Various combinations of SCMs in UHPC mix designs have been studied by many research groups. Most UHPC studies used SF as a main ingredient and parts of the cement were replaced with other SCMs in the literature. Although there are various combinations, most SCMs are placed in the ordinary categories: slag, FA, LP, and MK. Some other SCMs such as RHA, NP, NMC, DCP, CKD, GGP, BP and FGP are also investigated. The effects of the SCMs on the UHPC performances of early and late compressive strength, flowability, shrinkage, and the environmental impact are discussed comprehensively in the following sections. 
Table 1. Summary of the effects of supplementary cementitious materials (SCMs) on the UHPC performances.

\begin{tabular}{|c|c|c|c|c|}
\hline \multicolumn{2}{|c|}{ Performance } & \begin{tabular}{l}
\multicolumn{1}{c}{ SCM No. } \\
{$[$ Slag] 7, 13; [FA] 23, 25; } \\
{$[\mathrm{MK}] 32 ;[\mathrm{O}] 35$}
\end{tabular} & \multicolumn{2}{|c|}{ List of SCMs } \\
\hline $\begin{array}{l}\text { Early compressive } \\
\text { strength ( } \leq 3 \text { days) }\end{array}$ & High & $\begin{array}{l}\text { [Slag] 1, 2, 3, 9, 11, 12, 15; } \\
\text { [FA] 18, 19, 21; [LP] 29; } \\
\text { [MK] 33; [O] 37, 38, 39, } 43\end{array}$ & $\begin{array}{l}\text { [Slag] } \\
\text { (1) GGBS }(\mathbf{6 0} \%)+\text { SF [39] } \\
\text { (2) GGBS }(\mathbf{2 5 . 5 \% )}+\text { SF + } \\
\text { BA [40] } \\
\text { (3) GGBS (30\%) + SF [41] } \\
\text { (4) GGBS (38.5\%) + SF } \\
\text { [42] } \\
\text { (5) GGBS (30\%) [43] }\end{array}$ & $\begin{array}{l}\text { Limestone powder [LP] } \\
(26-1) \text { LP (37.3\%) + SF [57] } \\
\text { (26-2) LP (57.2-78.1\%) + } \\
\text { SF [57] } \\
\text { (27) LP (32\%) + SF [58] } \\
\text { (28) LP (4\%) + SF [49] } \\
\text { (29) LP (14\%) + SF + FA } \\
\text { [59] }\end{array}$ \\
\hline $\begin{array}{l}\text { Late compressive strength } \\
\text { ( }>3 \text { days) }\end{array}$ & High & $\begin{array}{l}\text { [Slag] 1, 2, 5, 6, 7, 9, 12, 14, } \\
\text { 15, 16; [FA] 20, 24; [LP] } \\
\text { 26-1, 27, 30; [MK] 32; [O] } \\
35,41,42 \\
\\
{[\text { [Slag] 3, 4, 8, 10, 11; [FA] }} \\
\text { 17, 18, 19, 21, 22; [LP] 26-2, } \\
28,29 ;[\mathrm{MK}] 31,34,32 ;[\mathrm{O}] \\
36,37,38,39,40,43\end{array}$ & $\begin{array}{l}\text { (6) GGBS }(\mathbf{2 0}-\mathbf{4 0} \%)+\mathrm{SF} \\
\text { [44] } \\
\text { (7) GGBS }(\mathbf{2 3 . 6 \% )}+\mathrm{SF} \\
\text { [45] } \\
\text { (8) FGGBS }(\mathbf{3 8 . 5} \%)+\mathrm{SF} \\
\text { [42] } \\
\text { (9) FGGBS }(\mathbf{8 . 4} \%)+\mathrm{SF}+ \\
\text { BA [40] } \\
\text { (10) SSP (16.9\%) + SF [46] } \\
\text { (11) SSP (15\%) + LP + SF }\end{array}$ & $\begin{array}{l}\text { (30) NC (3.2\%) + SF [60] } \\
\text { Metakaolin [MK] } \\
\text { (31) MK (20\%) + SF [61,62] } \\
\text { (32) MK (16.7\%) [63] } \\
\text { (33) NMK (1\%) + MK [64] } \\
\text { (34) MK (6.9\%) + SF [65] } \\
\text { Others [O] } \\
\text { (35) RHA (10\%) + SF [66] } \\
\text { (36) NP (11.8\%) + SF [49] } \\
\text { (37) NP (24\%) + SF [67] }\end{array}$ \\
\hline Flowability & High & $\begin{array}{l}\text { [Slag] 2, 4, 6, 7, 8, 9, 10, 12; } \\
\text { [FA] 22, 24, 25; [LP] 26-1, } \\
26-2,28,29 ;[\mathrm{O}] 41,42,43\end{array}$ & $\begin{array}{l}{[12]} \\
\text { (12) PS (6.9-34.2\%) + SF + } \\
\text { FA [47] } \\
\text { (13) PS }(\mathbf{3 5} \%)+\text { SF [48] } \\
\text { (14) PSS (4\%) + SF [49] } \\
\text { (15) LTS (10\%) + SF [50] } \\
\text { (16) CS (16\%) + SF [51] } \\
\text { Fly ash [FA] } \\
\text { (17) FA (11.8\%) + SF [49] }\end{array}$ & $\begin{array}{l}\text { (38) NMC (1-9\%) + MK } \\
\text { [68] } \\
\text { (39) DCP ( } \leq \mathbf{9 \% )}+\text { SF + } \\
\text { LP [69] } \\
\text { (40) CKD (4\%) + SF [49] } \\
\text { (41) GGP (11.5\%) + SF [70] } \\
\text { (42) FGP (6-15\%) + SF [71] } \\
\text { (43) BP (14\%)+ SF + FA } \\
\text { [59] }\end{array}$ \\
\hline Shrinkage & High & $\begin{array}{l}\text { [Slag] 11, 12; [FA] 23, 24; } \\
\text { [LP] 26-2, 29; [MK] 32; [O] } \\
43\end{array}$ & 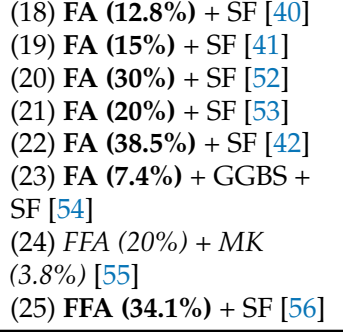 & \\
\hline
\end{tabular}

\section{Effect of SCMs on Material Properties of UHPC}

\subsection{Slag}

Slag is the by-product in pig iron, steel, lithium carbonate, phosphor, or copper plants and their primary oxide components are $\mathrm{CaO}, \mathrm{SiO}_{2}$, and $\mathrm{Al}_{2} \mathrm{O}_{3}$, although the proportions are not the same among different sources [72]. The effects of slag on UHPC compressive strength, flowability, and shrinkage are summarized in Tables $2-4$, respectively. They also include information such as the water to binder $(\mathrm{w} / \mathrm{b})$ ratio, the curing method, specimen size, the superplasticizer to binder $(\mathrm{SP} / \mathrm{b})$ ratio, the aggregate to binder $(\mathrm{Agg} / \mathrm{b})$ ratio, the mixture type, and other solid ingredients. The same types of tables are used for other SCMs in the following subsections. 
Table 2. The effect of slag on the compressive strength of UHPC.

\begin{tabular}{|c|c|c|c|c|c|c|}
\hline SCMs & $\begin{array}{c}\text { Compressive Strength } \\
\text { (MPa @ Age } \\
\text { (\% to the Ref.)) }\end{array}$ & w/b Ratio & Curing Method & $\begin{array}{l}\text { Specimen Size } \\
(\mathrm{mm})\end{array}$ & Other Solid Ingredients & Ref. \\
\hline GGBS $(60 \%)+$ SF & $\begin{array}{l}127 @ 7(-7.1 \%) \\
162 @ 28(5.2 \%) \\
181 @ 90(8.4 \%) \\
25 @ 1(-39.0)\end{array}$ & 0.20 & Water & 50 cube & Cement (CEM I 52.5 N), Sand & [39] \\
\hline GGBS $(25.5 \%)+\mathrm{SF}+\mathrm{BA}$ & $\begin{array}{c}25 @ 1(-39.0 \%) \\
77 @ 3(-18.1 \%) \\
145 @ 28(0 \%) \\
157 @ 91(0.06 \%)\end{array}$ & 0.15 & Water & 50 cube & $\begin{array}{l}\text { Cement (CEM I), Sand, Steel } \\
\text { fiber (1 vol.\%), Silica powder }\end{array}$ & [40] \\
\hline GGBS $(30 \%)+S F$ & $\begin{array}{c}98 @ 3(-5.7 \%) \\
144 @ 28(-4.0 \%)\end{array}$ & 0.16 & Water & $40 \times 40 \times 80$ & $\begin{array}{c}\text { Cement (CEM I } 42.5 \text { R), Sand, } \\
\text { Steel fiber ( } 2 \text { vol. } \% \text { ) }\end{array}$ & [41] \\
\hline GGBS $(38.5 \%)+S F$ & $139.4 @ 28(-16.1 \%)$ & 0.20 & Water and air & 100 cube & $\begin{array}{c}\text { Cement (CEM I 42.5), Sand, } \\
\text { Steel fiber (2 vol.\%) }\end{array}$ & [42] \\
\hline GGBS $(30 \%)$ & $\begin{array}{c}123 @ 28(10 \%) \\
130 @ 91(-5.4 \%)\end{array}$ & 0.18 & Water & $40 \times 40 \times 160$ & Cement (CEM I 52.5 R), Sand & [43] \\
\hline GGBS $(20-40 \%)+S F$ & $110-120 @ 28(0-9 \%)$ & 0.18 & Water & 50 cube & Cement (CEM I), Sand & [44] \\
\hline GGBS $(23.6 \%)+S F$ & $\begin{array}{l}110 @ 3(0.0 \%) \\
125 @ 7(3.3 \%)\end{array}$ & 0.14 & Air & $40 \times 40 \times 160$ & Cement (CEM I 52.5 N), Sand & [45] \\
\hline FGGBS $(38.5 \%)+S F$ & $163.5 @ 28(-1.5 \%)$ & 0.20 & Water and air & 100 cube & $\begin{array}{c}\text { Cement (CEM I } 42.5 \text { R), Sand, } \\
\text { Steel fiber ( } 2 \text { vol. } \% \text { ) }\end{array}$ & [42] \\
\hline FGGBS $(8.4 \%)+S F+B A$ & $\begin{array}{c}13 @ 1(-68.3 \%) \\
101 @ 3(7.4 \%) \\
151 @ 28(4.1 \%) \\
165 @ 91(5.8 \%)\end{array}$ & 0.15 & Water & 50 cube & $\begin{array}{l}\text { Cement (CEM I), Sand, Steel } \\
\text { fiber ( } 1 \text { vol.\%), Silica powder }\end{array}$ & [40] \\
\hline SSP $(16.9 \%)+$ SF & $140 @ 28(-10.3 \%)$ & 0.13 & Heat, water & 100 cube & $\begin{array}{l}\text { Cement (CEM I 42.5), Sand, } \\
\text { Coarse agg., Steel fiber (1.6 } \\
\text { vol. } \% \text { ) }\end{array}$ & [46] \\
\hline $\operatorname{SSP}(15 \%)+\mathrm{LP}+\mathrm{SF}$ & $\begin{array}{c}68 @ 1(-8.7 \%) \\
142 @ 28(-6.4 \%)\end{array}$ & 0.16 & Water & 100 cube & $\begin{array}{c}\text { Cement (CEM I 42.5), Sand, } \\
\text { Quartz powder, Steel fiber ( } 2 \\
\text { vol. } \% \text { ) }\end{array}$ & [12] \\
\hline PS $(27.4 \%)+\mathrm{SF}+\mathrm{FA}$ & $\begin{array}{r}60 @ 3(-27.7 \%) \\
127.5 @ 28(2.8 \%)\end{array}$ & 0.17 & Air & $40 \times 40 \times 160$ & Cement (CEM I), Sand & [47] \\
\hline PS $(35 \%)+S F$ & $156.8 @ 3(3.7 \%)$ & 0.14 & Heat & $40 \times 40 \times 160$ & Cement (CEM I 52.5), Sand & [48] \\
\hline PSS $(4 \%)+$ SF & $161 @ 28(0.0 \%)$ & 0.15 & Water & & $\begin{array}{l}\text { Cement (CEM I), Sand, Steel } \\
\text { fiber ( } 2 \text { vol. } \%)\end{array}$ & [49] \\
\hline LTS $(10 \%)+S F$ & $\begin{array}{l}98 @ 3(-4.8 \%) \\
146 @ 28(2.8 \%) \\
156 @ 90(6.8 \%)\end{array}$ & 0.18 & Water & 40 cube & Cement (CEM I 52.5), Sand & [50] \\
\hline $\mathrm{CS}(16 \%)+\mathrm{SF}$ & $167 @ 90(3.1 \%)$ & 0.15 & Water & $40 \times 40 \times 160$ & Cement (CEM I 52.5 N), Sand & [51] \\
\hline
\end{tabular}

Table 3. Effect of slag on the flowability of UHPC.

\begin{tabular}{|c|c|c|c|c|c|c|c|c|}
\hline \multirow[t]{2}{*}{ SCMs } & \multicolumn{3}{|c|}{$\begin{array}{c}\text { Flowability } \\
\text { (mm (\% to the Ref.)) }\end{array}$} & \multirow[t]{2}{*}{ w/b Ratio } & \multirow{2}{*}{$\begin{array}{l}\mathrm{SP} / \mathrm{b} \\
\text { Ratio }\end{array}$} & \multirow[t]{2}{*}{ Agg/b Ratio } & \multirow[t]{2}{*}{ Type } & \multirow[t]{2}{*}{ Ref. } \\
\hline & Slump Flow & Flow Table & Mini Slump & & & & & \\
\hline $\begin{array}{l}\text { FGGBS (8.4\%) } \\
\quad+\text { SF + BA }\end{array}$ & $\begin{array}{c}675 \\
(11.6 \%)\end{array}$ & & & 0.15 & $0.75 \%$ & 0.70 & $\begin{array}{l}\text { Mortar + } \\
\text { Steel fiber (1 } \\
\text { vol. } \%)\end{array}$ & [40] \\
\hline $\begin{array}{l}\text { GGBS (25.5\%) } \\
\quad+\text { SF + BA }\end{array}$ & $\begin{array}{c}630 \\
(4.1 \%)\end{array}$ & & & 0.15 & $0.49 \%$ & 0.70 & $\begin{array}{l}\text { Mortar + } \\
\text { Steel fiber (1 } \\
\text { vol. } \%)\end{array}$ & [40] \\
\hline SSP (15\%) + LP + SF & $\begin{array}{c}605 \\
(-0.1 \%)\end{array}$ & & & 0.16 & $1.80 \%$ & 1.00 & $\begin{array}{l}\text { Mortar }+ \\
\text { Steel fiber (2 } \\
\text { vol. } \%)\end{array}$ & [12] \\
\hline $\begin{array}{l}\text { PS (34.2\%) } \\
+ \text { SF + FA }\end{array}$ & & $\begin{array}{c}306 \\
(17.2 \%)\end{array}$ & & 0.17 & $3.47 \%$ & 0.90 & Mortar & [47] \\
\hline FGGBS $(38.5 \%)+S F$ & $\begin{array}{c}310 \\
(10.7 \%)\end{array}$ & & & 0.20 & $3.50 \%$ & 1.44 & $\begin{array}{l}\text { Mortar }+ \\
\text { Steel fiber (2 } \\
\text { vol. } \%)\end{array}$ & [42] \\
\hline GGBS $(23.6 \%)+S F$ & & & $\begin{array}{c}300 \\
(0.0 \%)\end{array}$ & 0.14 & $0.90 \%$ & 1.00 & Mortar & [45] \\
\hline GGBS $(38.5 \%)+S F$ & $\begin{array}{c}285 \\
(1.8 \%)\end{array}$ & & & 0.20 & $3.50 \%$ & 1.44 & $\begin{array}{l}\text { Mortar + } \\
\text { Steel fiber (2 } \\
\text { vol. } \%)\end{array}$ & [42] \\
\hline GGBS $(20-40 \%)+S F$ & & & $\begin{array}{c}256 \\
(34.7 \%)\end{array}$ & 0.18 & $2.40 \%$ & 1.22 & Mortar & [44] \\
\hline SSP $(16.9 \%)+$ SF & & $\begin{array}{c}130 \\
(26.8 \%)\end{array}$ & & 0.13 & $5.42 \%$ & 1.25 & Mortar & [46] \\
\hline
\end{tabular}


Table 4. Effect of slag on the shrinkage of UHPC.

\begin{tabular}{|c|c|c|c|c|c|c|c|c|}
\hline \multirow{2}{*}{ SCMs } & \multicolumn{3}{|c|}{ Shrinkage } & \multirow{2}{*}{ w/b Ratio } & \multicolumn{3}{|c|}{ Binder Weight Ratio } & \multirow{2}{*}{ Ref. } \\
\hline & Auto & Dry & Total & & Cement & Slag & SF & \\
\hline SSP $(15 \%)+L P+S F$ & & & Low & 0.16 & 0.55 & 0.35 & 0.10 & [12] \\
\hline PS $(34.2 \%)+S F+F A$ & Low & & & 0.17 & 0.34 & 0.53 & 0.13 & [47] \\
\hline GGBS $(40 \%)+S F$ & High & & & 0.18 & 0.40 & 0.40 & 0.20 & {$[44]$} \\
\hline
\end{tabular}

Slag tends to decrease the compressive strength of UHPC at an early age because of its low reactivity. Slag has hydraulic properties and reacts with water [73] and the hydration product of slag is calcium silicate hydrate (CSH) $[43,74]$. Slag is chemically activated by calcium hydroxide $\left(\mathrm{Ca}(\mathrm{OH})_{2}\right)$ and gypsum in cement, but its reaction speed is slow, whereas SF reacts with $\mathrm{Ca}(\mathrm{OH})_{2}$ first in UHPC because of its fineness $[44,75]$. Researchers have also reported that slag decreases the heat of hydration $[39,43]$. As a result, slag tends to decrease the compressive strength of UHPC at 3 days or earlier. Most of the research revealed that the compressive strengths at 3 days of the UHPCs with slag decrease by around $4.8-18.1 \%$ from the reference specimens. Pyo and Kim revealed that the addition of GGBS decreases the compressive strength at 1 day and 3 days by $39 \%$ and $18 \%$, respectively [40]. They claimed that GGBS slow down the hydration process and setting time, which causes low early strength. Li et al. reported that SSP improves the workability even though it degrades the mechanical properties and durability of UHPC [12] The $15 \%$ replacement of cement with SSP results in $8.7 \%$ lower compressive strength at 1 day than that of the reference specimen. As the SSP has a low hydration activity as well as a retarding effect on the cement hydration, the activity of SSP is lower than OPC and it slowed down the early age hydration. He et al. replaced SF with the LTS that is a by-product in the process of lithium carbonate [50]. The $10 \%$ of the LTS to the total binder results in a $4.8 \%$ lower compressive strength at 3 days compared to the control mix with SF only. The addition of LTS decreases the early age compressive strength because the pozzolanic reaction of LTS is slower than SF.

Slag could enhance the late age compressive strength of UHPC; the secondary pozzolanic reaction between slag and $\mathrm{Ca}(\mathrm{OH})_{2}$ in the pore solution produces additional $\mathrm{CSH}$, which increases the packing density of the UHPC [44]. Liu et al. found that compressive strength increases up to $9 \%$ when GGBS content increased to $40 \%$ of the binder because the secondary pozzolanic reaction of GGBS is accompanied by consumption of $\mathrm{Ca}(\mathrm{OH})_{2}$ and the densification of the hardened paste [44]. Abdulkareem et al. reported that the use of GGBS can accelerate the hydration reaction of cement and also improve packing density because its fineness is between those of cement and SF [45]. When GGBS content increased to $23.6 \%$ of binder, the compressive strength increased by $3.3 \%$ at 7 days because of the improved packing density and higher cement hydration due to the addition of GGBS. Gupta used GGBS with 35\% calcium oxide content that contributes to CSH formation, and thus, improves strength development [39]. The 60\% replacement of cement with GGBS resulted in a 5.2\% increase in the UHPC's compressive strength at 28 days. Yu et al. reported a $10 \%$ increase in 28-day compressive strength by replacing $30 \%$ of the cement with GGBS [43]. He et al. successfully replaced $10 \%$ of cement with LTS and the compressive strength increases by $2.8 \%$ and $6.8 \%$ at 28 days and 90 days, respectively [50]. The fineness of LTS is between those of cement and SF, which can improve the packing density of UHPC and the pozzolanic reaction of LTS also contributes to the late age compressive strength development. Peng et al. used PS that has a similar glass structure to GGBS [48]. When PS content increased from 30\% to 35\%, the compressive strength increased by $3.7 \%$ because the addition of PS increased both the degree and speed of the pozzolanic reaction, which results in more hydration products in the paste and low porosity. The PS used by Yang et al. has relatively lower reactivity than ordinary slag because of the lower $\mathrm{Al}_{2} \mathrm{O}_{3}$ content [47]. $\mathrm{P}_{2} \mathrm{O}_{5}$ in the PS can also retard hydration at an early age. The PS of $27.4 \%$ of 
the binder was found to increase the compressive strength at 28 days by $6.3 \%$. The PS can yield small pores in microstructure at an early age and fill those by the hydration product from the long-term pozzolanic reaction. Edwin et al. proved that CS can be used as an SCM in UHPC increasing the amount of CSH [51]. CS is a by-product of the copper metal smelting process. When CS content increases up to $16 \%$ of the binder, the compressive strength of UHPC increases by $3.1 \%$ at 90 days. Ahmadm et al. studied the effect of using industrial waste materials like PSS to replace parts of SF [49]. When replacing $20 \%$ of SF, the compressive strength of UHPC can still reach $161 \mathrm{MPa}$ at 28 days, which is the same as that of the reference specimen with SF only and flow diameter slightly decreased, but it was still within the acceptable range.

The particle size of slag can be a critical factor in the compressive strength of UHPC. Randl et al. studied the effect of GGBS and FGGBS on the UHPC compressive strength [42]. The GGBS and FGGBS have the Blaine values of 4790 and $5620 \mathrm{~cm}^{2} / \mathrm{g}$, respectively. When $38.5 \%$ of cement is replaced with FGGBS, it decreases the compressive strength by $1.5 \%$, whereas GGBS decreases the strength by $16.1 \%$ because FGGBS results in a higher packing density than GGBS. The study concluded that the packing density of UPHC is an important factor even more than the hydraulic reactivity of slag. Pyo and Kim compared slags with different particle sizes [40]. The median particle size of FGGBS and GGBS are $2.69 \mu \mathrm{m}$ and $14 \mu \mathrm{m}$, respectively. They reported that the usage of FGGBS increases the compressive strength increased by $7.4 \%$ at 3 days, while GGBS decreases the compressive strength with the same dosage of FGGBS. From the hydration heat measurement, they concluded that FGGBS plays a significant role in the early hydration process, which results in a higher compressive strength than the reference specimen.

Some slags may decrease the porosity of UHPC. Liu and Guo studied the effect of SSP on the compressive strength of UHPC [46]. The particle size distribution of SSP is similar to that of cement. It was found that the compressive strength decreased rapidly when the SSP content is high. With the $16.9 \%$ replacement ratio of cement with SSP, the compressive strength decreased by $10.3 \%$ compared to the reference specimen that contains SF only because SSP increases the proportion of the pores larger than $50 \mathrm{~mm}$ by $33 \%$.

The effect of slag on the UHPC shrinkage possibly depends on the type of slag. Table 4 summarizes the effect of slag on the UHPC shrinkage. It has been proved that the addition of GGBS increases the shrinkage of conventional concrete because slag increases the self-desiccation by consuming pore solution (calcium hydroxide) in a small capillary pore structure [76-78]. However, different effects of different types of slags on the UPHC shrinkage have been observed in some studies in the literature. Li et al. found that the total shrinkage of UHPC incorporating SSP is lower than the UHPC without SSP [12]. As the amount of SSP increases, hydration of cementitious materials decreases at early ages, water consumption is reduced, and, thus, the self-desiccation of UHPC becomes weaker. Yang et al. indicated that as the cement replacement ratio with PS increases, the hydration can be slowed down and the cement dilution effect can improve the UHPC volume stability [47]. In other words, the high volume of PS can reduce the autogenous shrinkage of UHPC. On the other hand, Liu et al. found that the addition of GGBS can increase autogenous shrinkage [44]. They insisted that the secondary pozzolanic reaction of GGBS increases the consumption of calcium hydroxide, which increases water consumption. The higher water consumption results in more self-desiccation. They concluded that the secondary pozzolanic reaction of GGBS increases the autogenous shrinkage due to the refined pore structure and the increased depletion of water.

Slag increases the UHPC flowability because of its lower water absorption compared to cement having a slippery surface [79]. Table 3 summarizes the effect of slag on the UHPC flowability. Pyo and Kim reported that the addition of FGGBS and GGBS increases the UHPC flowability by $11.6 \%$ and $4.1 \%$, respectively, compared to the reference specimen with SF only [40]. Yang et al. reported that the use of PS can significantly improve the flowability of UHPC. The flowability of UHPC can increase by $17.2 \%$ when the cement replacement ratio with PS increased up to $34.2 \%$ because it reduces the water absorption [47]. 
Furthermore, the addition of PS provides the cement dilution effect, which increases the water to cement ratio of UHPC with PS indirectly. Abdulkareem et al. reported that the workability is improved by the addition of GGBS [45]. In the paper, with the increase in GGBS, the dosage of superplasticizer should be reduced to achieve the same level of slump flow. Liu et al. used GGBS to improve the flowability of UHPC. With up to $30 \%$ replacement of cement with GGBS, the slump flow can increase by $6.3 \%$ because of the smooth surface and lower water absorption of the slag compared to cement [44]. Liu and Guo proved that the addition of SSP can improve the flowability of UHPC. The $16.9 \%$ replacement ratio of cement increases the flow diameter by $26.8 \%$ because the activity of SSP is lower than that of cement and the water requirement of SSP is also less than that of cement [46]. However, $\mathrm{Li}$ et al. found that the $15 \%$ replacement of cement with the different SSP source slightly decreases the flowability of UHPC because of the higher specific area than that of cement, which caused higher water demand [12]. Therefore, it should be pointed out that a higher specific area of different sources of slag could decrease the flowability of UHPC. Randl et al. found that the specific area of GGBS and FGGBS can improve the flowability of UHPC [42]. The slump flow of UHPC increased by $1.8 \%$ with $38.5 \%$ GGBS replacement and the slump flow of UHPC increased by $10.7 \%$ with $38.5 \%$ FGGBS replacement.

Slag is possibly more helpful than FA to improve the UHPC's compressive strength. $\mathrm{Wu}$ et al. reported that when the cement replacement ratio is same, slag exhibits a higher compressive strength of UHPC than FA [41]. The 30\% replacement ratio of cement with GGBS results in $5.7 \%$ and $4.0 \%$ lower at 3 days and 28 days, respectively, compared to the reference specimen containing SF only, while the 30\% replacement with FA results in 13.5\% and $8.0 \%$ lower at 3 days and 28 days, respectively.

Although slag is apt to decrease the early compressive strength of UHPC, many studies have demonstrated that it successfully improves the late compressive strength. The additional CSH produced by the secondary pozzolanic reaction between slag and $\mathrm{Ca}(\mathrm{OH})_{2}$ increases the density of the matrix and the compressive strength, which happens at the late age because of the slow hydration of slag. The disadvantage of the low early compressive strength is assumed to be overcome by adopting heat treatment as it increases the pozzolanic reactivity. The particle size of slag is also an important factor to increase the compressive strength of UHPC; slag of a finer particle size exhibits higher compressive strength. However, the extra grinding work increases the material cost and, therefore, finding reactive slag material seems a more efficient option. Slag decreases the water demand of UHPC because of its lower water absorption compared to cement. It is another critical factor to increase the compressive strength of UHPC because a lower $\mathrm{w} / \mathrm{c}$ ratio can increase the compressive strength.

\subsection{Fly Ash (FA)}

FA is a by-product of power plants and is collected during the process of coal combustion. The chemical composition and particle size of FA are different from plant to plant, but it is generally a fine spherical powder, which increases the workability of conventional cementitious material. As a pozzolanic material, it is known that FA increases the late age strength of conventional cementitious material. The usage of FA can reduce $\mathrm{CO}_{2}$ emissions $[55,66]$ and decrease the production cost and energy of concrete $[41,49,53,55]$. In recent years, many researchers have focused on developing new UHPC mixtures with locally available FA because substituting cement and/or SF with FA can reduce environmental impacts.

The effect of FA on UHPC compressive strength is summarized in Table 5. The compressive strength data reported show around $95 \mathrm{MPa}$ at 3 days, $110-185 \mathrm{MPa}$ at 28 days, and 152-202 MPa at 91 days with a 10-20\% replacement of binder materials. It has been shown that the UHPC with FA exhibits a lower compressive strength than those of reference specimens. Ahmad et al. replaced a part of SF with FA, and found that using FA to substitute the SF to up to $11.8 \%$ of the binder slightly decreases the compressive strength by $1.9 \%$ compared to the reference specimen at 28 days [49]. Although FA degrades the 
compressive strength of UHPC, the value is higher than the minimum requirement of $150 \mathrm{MPa}$ and the usage of FA can reduce the cost of UHPC. It has been proved that FA can improve many characteristics of high strength mortar. However, Pyo et al. found that replacing $12.8 \%$ cement with FA decreased the compressive strength by $48.9 \%$ and $6.1 \%$ at 1 day and 3 days, respectively, because of the high crystallinity of FA [40]. Wu et al. also investigated the effect of FA as an SCM for concrete, and concluded that the FA has negative effects on the compressive strength of UHPC [41]. The 15\% replacement ratio of cement with FA results in $13.5 \%$ and $8 \%$ lower than those of reference specimen at 3 days and 28 days, respectively. Alsalman et al. adopted that FA can be used as an SCM for UHPC to reduce the cost of UHPC [53]. It was found that adding FA up to $15 \%$ of the binder significantly decreases the compressive strength by $33.7 \%$ at 1 day because the addition of FA delayed the strength development at early ages. The compressive strength of UHPC becomes similar to that of the reference specimen after the normal curing of 7 days or longer. Randl et al. found that the $38.5 \%$ replacement ratio of cement with FA decreases the compressive strength by $24.9 \%$ at 28 days compared to the reference specimen, even though the packing density is higher [42]. Therefore, it is inferred that the slow pozzolanic reaction of FA degrades the compressive strength of UPHC. It should be noted, however, that there are occasional studies reporting different trends. Šeps et al. replaced the cement of $30 \%$ with FA and it results in 19\% higher compressive strength at 28 days than that of the reference specimen containing SF only [52].

Table 5. The effect of FA on the compressive strength of UHPC.

\begin{tabular}{|c|c|c|c|c|c|c|}
\hline SCMs & $\begin{array}{l}\text { Compressive } \\
\text { Strength } \\
\text { (MPa @ Age } \\
\text { (\% to the Ref.)) }\end{array}$ & w/b Ratio & $\begin{array}{l}\text { Curing } \\
\text { Method }\end{array}$ & $\begin{array}{l}\text { Specimen Size } \\
(\mathrm{mm})\end{array}$ & Other Solid Ingredients & Ref. \\
\hline FA $(11.8 \%)+S F$ & $158 @ 28(-1.9 \%)$ & 0.15 & Water & 50 cube & $\begin{array}{l}\text { Cement (CEM I), Sand, } \\
\text { Steel fiber (2 vol. } \% \text { ) }\end{array}$ & [49] \\
\hline FA $(12.8 \%)+S F$ & $\begin{array}{c}24 @ 1(-48.9 \%) \\
92 @ 3(-6.1 \%) \\
152 @ 28(-1.3 \%) \\
164 @ 91(0 \%)\end{array}$ & 0.15 & Water & 50 cube & $\begin{array}{l}\text { Cement (CEM I), Sand, } \\
\text { Steel fiber (1 vol.\%) }\end{array}$ & [40] \\
\hline FA $(\mathbf{1 5 \%})+\mathrm{SF}$ & $\begin{array}{l}90 @ 3(-13.5 \%) \\
138 @ 28(-8 \%)\end{array}$ & 0.20 & Water & $40 \times 40 \times 80$ & $\begin{array}{l}\text { Cement (CEM I 42.5), } \\
\text { Sand }\end{array}$ & [41] \\
\hline FA $(30 \%)+S F$ & $125 @ 28$ (19\%) & 0.26 & Air & 100 cube & $\begin{array}{c}\text { Cement (CEM I), Sand, } \\
\text { Coarse agg. }\end{array}$ & [52] \\
\hline FA $(20 \%)+S F$ & $\begin{array}{c}53.1 @ 1(-33.7 \%) \\
101.5 @ 7(-1.26 \%) \\
114.5 @ 28(-0.7 \%) \\
131.7 @ 56(2.1 \%) \\
152.1 @ 90(-1.9 \%)\end{array}$ & 0.16 & Water & 50 cube & $\begin{array}{l}\text { Cement (CEM I), Sand, } \\
\text { Steel fiber (3 vol.\%) }\end{array}$ & [53] \\
\hline $\mathrm{FA}(38.5 \%)+\mathrm{SF}$ & $124.7 @ 28(-24.9 \%)$ & 0.20 & Water and air & 100 cube & $\begin{array}{l}\text { Cement (CEM I } 42.5 \text { R), } \\
\text { Sand, Steel fiber (2 vol.\%) }\end{array}$ & [42] \\
\hline FA $(7.4 \%)+$ GGBS + SF & $281 @ 1(4.1 \%)$ & 0.15 & Autoclave & 50 cube & $\begin{array}{l}\text { Cement (CEM I 42.5), } \\
\text { Sand }\end{array}$ & [54] \\
\hline FFA $(20 \%)+$ MK $(3.8 \%)$ & $150 @ 28(26 \%)$ & 0.20 & Water & 50 cube & Cement (CEM III) & [55] \\
\hline FFA $(34.1 \%)+S F$ & $160.3 @ 3(6.8 \%)$ & 0.16 & $\begin{array}{l}\text { Water and } \\
\text { steam }\end{array}$ & 50 cube & $\begin{array}{l}\text { Cement (CEM I } 42.5 \text { R), } \\
\text { Sand, Steel fiber (1 vol.\%) }\end{array}$ & [56] \\
\hline
\end{tabular}

Some of the FFA can improve the compressive strength of UHPC. Ferdosian and Camões introduced the method of how to optimize the UHPC mix design that satisfies the requirements of the compressive strength and the flowability using FFA of which the mean particle size is $4.48 \mu \mathrm{m}$ [56]. They suggested the eco-efficient mix design that releases the lowest $\mathrm{CO}_{2}$ and the cost-efficient mix design that maximizes the amount of FFA and sand as well as minimizes the amount of SF. The eco-efficient mix design results in the compressive strength being $6.8 \%$ higher than the reference samples using the FFA of $34.1 \%$ in the binder.

The ternary use of SCMs including FA also can be a feasible solution to reduce the amount of cement and SF in UHPC. Li found that the ternary use of FA, MK, and 
cement can provide better compressive strength of UHPC than the binary use of SF and cement [55]. The $20 \%$ and $3.8 \%$ of cement were replaced with FA and MK, respectively, and the compressive strength increased by $26 \%$ at 28 days. Yazic1 et al. found that the ternary SF-FA-GGBS binder system is effective for reducing SF and water demand without sacrificing compressive strength [54]. In the binder system, the $10 \%$ replacement ratio of cement with FA increased the compressive strength by $4.1 \%$ up to $281 \mathrm{MPa}$ at 1 day under the autoclave curing condition. However, a fundamental understanding of the ternary use of SCMs improving mechanical properties of UHPC is still not clear and requires further research.

Table 6 summarizes the effect of FA on the UHPC flowability, which is controversial among studies. Some researchers reported that FA can improve the workability of UHPC. Li found that the ternary use of FA, MK, and cement can significantly increase the flowability of UHPC by $47 \%$ compared to the binary use of cement and SF [55]. Randl et al. found that the addition of FA can increase the flowability of UHPC [42]. The 38.5\% replacement ratio of cement with FA can increase the flow diameter of fresh UHPC by $3.6 \%$ compared to the reference specimen with SF only. Ferdosian and Camões focused on developing a mixing design method to minimize $\mathrm{CO}_{2}$ content and material cost with acceptable compressive strength and workability [56]. The $34.1 \%$ FA in the cementitious binder satisfied the low limit of flowability of $190 \mathrm{~mm}$. However, degradation of workability by using FA in UHPC was reported. Pyo and Kim found that the $15.7 \%$ replacement of silica powder with FA decreases the slump flow by $6.6 \%$ compared to the reference specimen [40]. Ahmad et al. studied that the effect of FA replaces the SF in UHPC. It was found that when the use of FA as a replacement of SF and its content is increased to $11.8 \%$ of binder, the flowability of UHPC slightly decreases by $8.7 \%$ than the reference specimen with SF only but the lower flowability is still acceptable [49].

Table 6. The effect of FA on the flowability of UHPC.

\begin{tabular}{|c|c|c|c|c|c|c|c|c|}
\hline \multirow[t]{2}{*}{ SCMs } & \multicolumn{3}{|c|}{$\begin{array}{c}\text { Flowability } \\
\text { (mm (\% to the Ref.)) }\end{array}$} & \multirow[t]{2}{*}{ w/b Ratio } & \multirow[t]{2}{*}{ SP/b Ratio } & \multirow{2}{*}{$\begin{array}{c}\text { Agg/b } \\
\text { Ratio }\end{array}$} & \multirow[t]{2}{*}{ Type } & \multirow[t]{2}{*}{ Ref. } \\
\hline & Slump Flow & Flow Table & Mini Slump & & & & & \\
\hline FA $(12.8 \%)+S F$ & $\begin{array}{c}565 \\
(-6.6 \%)\end{array}$ & & & 0.15 & $0.75 \%$ & 0.71 & $\begin{array}{l}\text { Mortar + Steel } \\
\text { fiber (1 vol. } \% \text { ) }\end{array}$ & [40] \\
\hline $\mathrm{FA}(38.5 \%)+\mathrm{SF}$ & $\begin{array}{c}290 \\
(3.6 \%)\end{array}$ & & & 0.20 & $3.50 \%$ & 1.44 & $\begin{array}{l}\text { Mortar + Steel } \\
\text { fiber (2 vol. } \%)\end{array}$ & [42] \\
\hline $\begin{array}{c}\text { FFA }(\mathbf{2 0} \%)+\mathrm{MK} \\
(3.8 \%)\end{array}$ & & $\begin{array}{c}258 \\
(47 \%)\end{array}$ & & 0.20 & $1.00 \%$ & - & Paste & [55] \\
\hline FA $(11.8 \%)+S F$ & & & $\begin{array}{c}210 \\
(-8.7 \%)\end{array}$ & 0.15 & $3.57 \%$ & 0.90 & $\begin{array}{l}\text { Mortar }+ \text { Steel } \\
\text { fiber }(2 \text { vol. } \%)\end{array}$ & [49] \\
\hline FFA $(34.1 \%)+S F$ & & $\begin{array}{c}190 \\
(0.0 \%)\end{array}$ & & 0.16 & $2.50 \%$ & 1.07 & $\begin{array}{l}\text { Mortar + Steel } \\
\text { fiber (1 vol. } \%)\end{array}$ & [56] \\
\hline
\end{tabular}

Table 7 summarizes the effect of FA on UHPC shrinkage. It has been shown that the FA can reduce the shrinkage of UHPC. Li et al. found that the ternary use of FA, MK, and cement can reduce the drying shrinkage of UHPC compared to the reference specimen with SF only because the ternary use can reduce water demand [55]. Yazıc1 et al. replaced cement with FA and GGBS to reduce the cement amount in UHPC [54]. It was found that when the content of GGBS in the binder is constant, the 10\% replacement ratio of cement with FA results in lower shrinkage than the reference specimen with SF only because of the lower amount of cement in UHPC.

The advantage of the usage of FA in UHPC cannot be observed in the compressive strength; most studies using FA reported degradation of the compressive strength of UHPC. The effect of FA on workability is arguable, and this might come from different characteristics of FAs from different sources. Therefore, the purpose of the usage of FA can be limited in reducing material cost or $\mathrm{CO}_{2}$ emission as discussed in the studies. Perhaps FA can increase the durability of UHPC; however, further studies are required to demonstrate it. 
Table 7. The effect of FA on the shrinkage of UHPC.

\begin{tabular}{|c|c|c|c|c|c|c|c|c|}
\hline \multirow{2}{*}{ SCMs } & \multicolumn{3}{|c|}{ Shrinkage } & \multirow{2}{*}{ w/b Ratio } & \multicolumn{3}{|c|}{ Binder Weight Ratio } & \multirow{2}{*}{ Ref. } \\
\hline & Auto & Dry & Total & & Cement & FA & SF & \\
\hline FFA $(20 \%)+M K(3.8 \%)$ & & Low & & 0.20 & 0.77 & 0.23 & - & [55] \\
\hline $\mathbf{F A}(\mathbf{8} \%)+\mathrm{GGBS}+\mathrm{SF}$ & & & Low & 0.15 & 0.64 & 0.16 & 0.20 & [54] \\
\hline
\end{tabular}

\subsection{Limestone Powder (LP)}

The effect of LP in conventional cement and concrete is well known; the use of LP in concrete has various advantages. It can reduce the material cost and $\mathrm{CO}_{2}$ emission because of having an abundant reservoir. LP has the nucleation effect in early hydration reaction that accelerates the cement hydration $[58,80]$. It can also physically fill the void and increase the packing density of the system [80]. As a consequence, LP increases the compressive strength of concrete at an early age. However, it may reduce the compressive strength at a late age because it does not have a pozzolanic reaction with cement unlike other SCMs such as slag, FA, and MK, and it requires higher water demand. In this section, the effect of LP in UHPC is reviewed

The effect of FA on UHPC compressive strength is summarized in Table 8. Three different mechanisms of how LP affects the compressive strength of UHPC were observed. First, $\mathrm{LP}$ enables the reduction in the amount of superplasticizer to maintain the same flowability. Huang et al. studied the effect of LP on the hydration of UHPC with different cement replacement ratios [58]. The retardation effect caused by the superplasticizer decreases as LP enables the reduction in the amount of superplasticizer by $62.8 \%$, and, as a result, the early compressive strength is not degraded. It was also found that the $32 \%$ replacement ratio of cement with LP results in $10.7 \%$ and $16.1 \%$ higher compressive strength at 28 days and 56 days, respectively.

Table 8. The effect of LP on the compressive strength of UHPC.

\begin{tabular}{|c|c|c|c|c|c|c|}
\hline SCMs & $\begin{array}{c}\text { Compressive } \\
\text { Strength } \\
\text { (MPa @ Age } \\
\text { (\% to the Ref.)) }\end{array}$ & w/b Ratio & $\begin{array}{l}\text { Curing } \\
\text { Method }\end{array}$ & $\begin{array}{l}\text { Specimen Size } \\
(\mathrm{mm})\end{array}$ & Other Solid Ingredients & Ref. \\
\hline $\mathbf{L P}(37.3 \%)+\mathrm{SF}$ & $159.5 @ 28(4.3 \%)$ & 0.20 & Water & 50 cube & $\begin{array}{l}\text { Cement (CEM I } 52.5 \text { R), } \\
\text { Sand }\end{array}$ & [57] \\
\hline $\mathrm{LP}(32 \%)+\mathrm{SF}$ & $\begin{array}{l}165 @ 28(10.7 \%) \\
180 @ 56(16.1 \%)\end{array}$ & 0.13 & Sealed & $40 \times 40 \times 160$ & $\begin{array}{l}\text { Cement (CEM I } 52.5 \mathrm{~N} \text { ), } \\
\text { Sand }\end{array}$ & [58] \\
\hline $\mathrm{LP}(4 \%)+\mathrm{SF}$ & $152 @ 28(-5.6 \%)$ & 0.15 & Water & 50 cube & $\begin{array}{l}\text { Cement (CEM I), Sand, } \\
\text { Steel fiber (2 vol. } \% \text { ) }\end{array}$ & [49] \\
\hline $\mathrm{LP}(\mathbf{1 4} \%)+\mathrm{SF}+\mathrm{FA}$ & $\begin{array}{c}100 @ 7(-4.2 \%) \\
120 @ 28(-1.1 \%) \\
140 @ 56(-4 \%)\end{array}$ & 0.16 & Water & $40 \times 40 \times 160$ & Cement (CEM I), Sand & [59] \\
\hline $\mathrm{NC}(3.2 \%)+\mathrm{SF}$ & $\begin{array}{c}120 @ 7(9 \%) \\
155 @ 28(15 \%)\end{array}$ & 0.16 & Water & $40 \times 40 \times 160$ & $\begin{array}{c}\text { Cement (CEM I 42.5), } \\
\text { Sand, Steel fiber (2 vol.\%) }\end{array}$ & [60] \\
\hline
\end{tabular}

Second, LP has a pozzolanic reaction with SF. Li et al. adopted that replacing cement with LP and the optimum content of $37.3 \%$ replacement ratio increases the compressive strength of UHPC by $4.3 \%$ at 28 days than that of the control mix with SF only [57]. As UHPC with LP has a higher pozzolanic reaction with SF, which contributes to the CSH formation at late ages, strength development can be improved at late ages.

Third, the fine particle-sized LP can accelerate cement hydration. Wu et al. reported the addition of nanoparticles such as NC can improve the mechanical properties and durability of UHPC [60]. It is found that the $3.2 \%$ replacement ratio of cement with NC increases the compressive strength of UHPC by $1.1 \%$ and $5 \%$ at 7 days and 28 days, respectively, because the use of $\mathrm{NC}$ accelerates the hydration of cement and makes the microstructure denser due to smaller particle size of NC compared to cement. 
However, in some cases, LP can degrade the compressive strength of UHPC. Yang et al. investigated the effect of LP on the hardened properties of the UHPC that contains FA and SF of $24 \%$ and $12 \%$, respectively [59]. The $14 \%$ replacement ratio of cement with LP decreases the compressive strength of UHPC by $4.2 \%$ at 7 days than that of the reference specimen with SF and FA. Although the compressive strengths of UHPC at 28 days and 56 days increase compared to day 7 compressive strength, these two strengths are still $1.1 \%$ and $4 \%$ lower than the reference specimen, respectively. Even though the LP has the nucleation effect increasing the cement hydration speed, it also dilutes the cement hydration resulting in lower heat of cement hydration. As the amount of LP increases in the low cement binder, the dilution effect becomes more dominant. Ahmad et al. studied the effect of the use of locally available industrial waste material such as LP as a partial substitution of SF [49]. The use of LP decreases the compressive strength of UHPC by $5.65 \%$ when the content of LP increases to $4 \%$ of the binder compared to the reference specimen with SF only.

LP can significantly improve the workability of UHPC as shown in Table 9. Li et al. insisted that LP can be regarded as a mineral plasticizer that improves the flowability of the UHPC [57]. The 37.3\% replacement ratio of cement with LP results in $45.1 \%$ higher flowability than that of the reference specimen that contains SF only. The plasticization effect of LP increases the workability of UHPC because of the repulsion between $\mathrm{OH}^{-}$group localized on the $\mathrm{Ca}^{2+}$ surface and its lower water absorption [57]. Yang et al. found that the use of LP as a partial substitution of cement can enhance the flowability of UHPC [59]. The $14 \%$ replacement ratio of cement with LP increases the flow diameter by $65.5 \%$ than the reference specimen with SF only. This can be attributed to the higher w/c ratio as a part of cement is replaced with LP. Ahmad et al. also found that the use of LP increases the flowability of UHPC by $10.9 \%$ when the content of LP is $4 \%$ of the binder compared to the reference specimen with SF only [49].

Table 9. The effect of LP on the flowability of UHPC.

\begin{tabular}{|c|c|c|c|c|c|c|c|c|}
\hline \multirow{2}{*}{ SCMs } & \multicolumn{3}{|c|}{$\begin{array}{c}\text { Flowability } \\
\text { (mm (\% to the Ref.)) }\end{array}$} & \multirow{2}{*}{$\begin{array}{l}\text { w/b } \\
\text { Ratio }\end{array}$} & \multirow{2}{*}{$\begin{array}{l}\mathrm{SP} / \mathrm{B} \\
\text { Ratio }\end{array}$} & \multirow{2}{*}{$\begin{array}{l}\text { Agg/b } \\
\text { Ratio }\end{array}$} & \multirow{2}{*}{ Type } & \multirow{2}{*}{ Ref. } \\
\hline & $\begin{array}{l}\text { Slump } \\
\text { Flow }\end{array}$ & $\begin{array}{l}\text { Flow } \\
\text { Table }\end{array}$ & $\begin{array}{l}\text { Mini } \\
\text { Slump }\end{array}$ & & & & & \\
\hline $\mathrm{LP}(4 \%)+\mathrm{SF}$ & & & $\begin{array}{c}255 \\
(10.9 \%)\end{array}$ & 0.15 & $3.57 \%$ & 0.90 & $\begin{array}{l}\text { Mortar + Steel } \\
\text { fiber (2 vol.\%) }\end{array}$ & [49] \\
\hline LP (14\%) + SF + FA & & $\begin{array}{c}240 \\
(65.5 \%)\end{array}$ & & 0.16 & $2.20 \%$ & 0.85 & Mortar & [59] \\
\hline $\mathrm{LP}(37.3 \%)+\mathrm{SF}$ & & & $\begin{array}{c}450 \\
(45.1 \%)\end{array}$ & 0.20 & $1.30 \%$ & 0.78 & Mortar & [57] \\
\hline
\end{tabular}

LP can lower the shrinkage of UHPC by reducing the amount of cement in UHPC as shown in Table 10. Li et al. found that a $57.2 \%$ replacement ratio of cement with LP can improve the total shrinkage of UHPC compared to that of the reference specimen with SF only [57]. The study insisted that the lower amount of cement in UHPC replaced with LP slows down the hydration and reduces the hydration products, and, thus, results in the lower autogenous shrinkage. It should be pointed out, however, that the high content of LP up to $78.1 \%$ of the binder provides more free water, and, thus, drying shrinkage increases. In consequence, the total shrinkage decreases because the reduction in autogenous shrinkage is greater than the increase in drying shrinkage. Yang et al. also reported that replacing $14 \%$ cement with LP reduces the autogenous and dry shrinkage compared to the reference specimen with SF only [59]. 
Table 10. The effect of LP on the shrinkage of UHPC.

\begin{tabular}{|c|c|c|c|c|c|c|c|c|}
\hline \multirow{2}{*}{ SCMs } & \multicolumn{3}{|c|}{ Shrinkage } & \multirow{2}{*}{$\begin{array}{c}\text { w/b } \\
\text { Ratio }\end{array}$} & \multicolumn{3}{|c|}{ Binder Weight Ratio } & \multirow{2}{*}{ Ref. } \\
\hline & Auto & Dry & Total & & Cement & LP & SF & \\
\hline LP (57.2) + SF & & & Low & 0.20 & 0.39 & 0.57 & 0.04 & [57] \\
\hline$L P(14 \%)+S F+F A$ & Low & Low & Low & 0.16 & 0.49 & 0.39 & 0.12 & [59] \\
\hline
\end{tabular}

Although three different mechanisms of how LP increases the compressive strength of UHPC have been proposed, the actual performance of LP in UHPC is debatable. From the literature, it was confirmed that LP increases the workability of UPHC. Therefore, the mechanism of LP to improve the compressive strength of UHPC by reducing water content seems appropriate. The finer LP enhances the compressive strength of UHPC by accelerating the cement hydration. Some studies insisted that the addition of LP decreases the amount of cement in UHPC, which degrades the compressive strength of UHPC. However, their dosages are lower than the other studies showing higher compressive strength with LP, and, therefore, other unknown factors of LP were assumed to degrade the compressive strength.

\subsection{Metakaolin (MK)}

MK obtained by calcining kaolin has the main chemical composition of alumina and silica, and, therefore, MK is also a pozzolanic material. Studies have reported that MK increases the durability of concrete: low permeability, high resistance against frost, and chemical attack [81-83].

The effect of MK on the UHPC compressive strength is summarized in Table 11. The use of MK only seems to increase the early age compressive strength of UHPC but decreases the late age compressive strength of UHPC. Li et al. found that replacing cement with MK can improve early age compressive strength but the late age compressive strength is decreased compared to UHPC with SF only [63]. It was found that the $16.7 \%$ replacement ratio of cement with MK results in $47 \%$ higher 1-day compressive strength than the reference specimen with SF only because the use of MK improves the cement hydration at an early age. However, it decreases the 28-day compressive strength by $11.8 \%$ compared to the reference sample, of which impact is less significant compared to that of 1-day compressive strength. Tafraoui et al. found a replacement of SF of $20 \%$ with MK decreasing the 28 -day compressive strength of UHPC by $26.1 \%$ with steam curing, and by $5.8 \%$ with water curing, respectively [61,62]. The more significant loss of $26.1 \%$ compared to $5.8 \%$, even with the same dosage of $\mathrm{MK}$, is because of the usage of the crushed quartz that can lower the compactness by a looseness of granular stacking.

Table 11. The effect of MK on the compressive strength of UHPC.

\begin{tabular}{|c|c|c|c|c|c|c|}
\hline SCMs & $\begin{array}{l}\text { Compressive Strength } \\
\text { (MPa @ Age } \\
\text { (\% to the Ref.)) }\end{array}$ & w/b Ratio & $\begin{array}{l}\text { Curing } \\
\text { Method }\end{array}$ & $\begin{array}{l}\text { Specimen Size } \\
(\mathrm{mm})\end{array}$ & $\begin{array}{l}\text { Other Solid } \\
\text { Ingredients }\end{array}$ & Ref. \\
\hline MK $(20 \%)+$ SF & $\begin{array}{c}119,178,183 @ 28 \\
(-26.1 \%, 8.7 \%,-13.7 \%) \\
\left(23^{\circ} \mathrm{C}, 90^{\circ} \mathrm{C}, 150^{\circ} \mathrm{C}\right)\end{array}$ & 0.22 & $\begin{array}{l}\text { Water at } 23^{\circ} \mathrm{C} \text {; } \\
\text { and steam at } 90 \\
\text { and } 150{ }^{\circ} \mathrm{C}\end{array}$ & $40 \times 40 \times 160$ & $\begin{array}{l}\text { Cement (CEM I 42.5), } \\
\text { Sand }\end{array}$ & {$[61]$} \\
\hline MK (20\%) + SF & $146 @ 28$ (-5.8\%) & 0.22 & Water & $40 \times 40 \times 160$ & $\begin{array}{c}\text { Cement (CEM I } 52.5 \\
\text { N), Sand }\end{array}$ & [62] \\
\hline MK (16.7\%) & $\begin{array}{c}106 @ 3(47.0 \%) \\
134 @ 28(-11.8 \%)\end{array}$ & 0.20 & Water & 50 cube & $\begin{array}{l}\text { Cement (CEM III), } \\
\text { Sand }\end{array}$ & [63] \\
\hline NMK (1\%) + MK & $\begin{array}{l}120 @ 3(-0.8 \%) \\
146 @ 7(-1.3 \%) \\
178 @ 28(7.9 \%)\end{array}$ & 0.20 & Heat & 100 cube & $\begin{array}{l}\text { Cement (CEM I), } \\
\text { Sand, Coarse agg. }\end{array}$ & [64] \\
\hline $\operatorname{MK}(6.9 \%)+$ SF & $163.8 @ 28(9.3 \%)$ & 0.25 & Sealed & 50 cube & $\begin{array}{c}\text { GGBS, SF, Potassium, } \\
\text { Sand } \\
\text { (Alkali-activated } \\
\text { material) }\end{array}$ & {$[65]$} \\
\hline
\end{tabular}


NMK may overcome the degradation of the UPHC compressive strength caused by MK. Muhd Norhasri et al. indicated that the inclusion of NMK in UHPC can achieve a similar compressive strength at early ages compared to the UHPC with MK only [64]. NMK inclusion of 1\% in UHPC can increase the compressive strength of UHPC at 28 days by $7.9 \%$ than that of the reference specimen with MK only because nano-MK provides a moderate ultra-filling effect in densifying the UHPC. The disadvantage of NMK is that it decreases the workability of UPHC; $1 \%$ NMK in UHPC decreases the slump flow by $2.4 \%$ because of the higher surface of NMK than that of MK (See Table 12).

Table 12. The effect of MK on the flowability of UHPC.

\begin{tabular}{|c|c|c|c|c|c|c|c|c|}
\hline \multirow{2}{*}{ SCMs } & \multicolumn{3}{|c|}{$\begin{array}{c}\text { Flowability } \\
\text { (mm (\% to the Ref.)) }\end{array}$} & \multirow{2}{*}{$\begin{array}{c}\text { w/b } \\
\text { Ratio }\end{array}$} & \multirow{2}{*}{$\begin{array}{l}\mathrm{SP} / \mathrm{b} \\
\text { Ratio }\end{array}$} & \multirow{2}{*}{$\begin{array}{l}\text { Agg/b } \\
\text { Ratio }\end{array}$} & \multirow{2}{*}{ Type } & \multirow{2}{*}{ Ref. } \\
\hline & $\begin{array}{l}\text { Slump } \\
\text { Flow }\end{array}$ & $\begin{array}{l}\text { Flow } \\
\text { Table }\end{array}$ & $\begin{array}{l}\text { Mini } \\
\text { Slump }\end{array}$ & & & & & \\
\hline NMK (1\%) + MK & $\begin{array}{c}162 \\
(-2.4 \%)\end{array}$ & & & 0.20 & $2.00 \%$ & 1.00 & Mortar & [64] \\
\hline
\end{tabular}

The effect of MK on the shrinkage of UHPC can be different concerning the type of shrinkage measured as shown in Table 13. Li and Rangaraju studied the effect of MK on the shrinkage of UHPC [63]. The addition of MK of $16.7 \%$ increases the autogenous shrinkage by $0.16 \%$, but it decreases the drying shrinkage by $0.1 \%$. However, no clear explanation of the different effects of MK on the different types of shrinkage is proposed.

Table 13. The effect of MK on the shrinkage of UHPC.

\begin{tabular}{|c|c|c|c|c|c|c|c|c|}
\hline \multirow{2}{*}{ SCMs } & \multicolumn{3}{|c|}{ Shrinkage } & \multirow{2}{*}{$\begin{array}{c}\text { w/b } \\
\text { Ratio }\end{array}$} & \multicolumn{3}{|c|}{ Binder Weight Ratio } & \multirow{2}{*}{ Ref. } \\
\hline & Auto & Dry & Total & & Cement & MK & SF & \\
\hline MK (16.7\%) & High & Low & & 0.20 & 0.83 & 0.17 & - & [63] \\
\hline
\end{tabular}

MK can be incorporated in alkali-activated material (AAM). Wetzel and Middendorf introduced the UHPC made by AAM. Slag, MK, and SF were mixed with hydroxide solution and glass water [65]. The specimens were cured at $60^{\circ} \mathrm{C}$ and exhibit a compressive strength at 28 days over $150 \mathrm{MPa}$. The alkalinity of AAM is higher than ordinary Portland cement; the $\mathrm{pH}$ of AAM is usually over 14, whereas that of ordinary Portland cement is 12.6-13.5. Due to the highly alkaline environment of AAM, SF even increases the workability of UPHC and MK reduces much less than the case of ordinary Portland cement. As a result, AAM concrete shows good workability. MK creates the geopolymer network of Si-O-T ( $\mathrm{Si}, \mathrm{Al})$ in AAM which increases the chemical attack resistance of UHPC.

MK tends to decrease the compressive strength of UHPC. It decreases the workability of UHPC and its beneficial effect on the shrinkage is not clear. Based on the fact that MK is not naturally stored but needs to be calcined, it also is difficult to find the merits of MK in material cost and $\mathrm{CO}_{2}$ emission compared to slag, FA, or LP. Therefore, the usage of MK in UHPC seems not suitable. However, another possible application was found; the geopolymer or alkali-activated concrete resulted in a compressive strength of over $150 \mathrm{MPa}$. As geopolymer is well known for its lower $\mathrm{CO}_{2}$ emission compared to OPC, developing geopolymer UHPC with MK can be an interesting research subject.

\subsection{Other SCMs}

Studies adopting other SCMs that do not belong to the SCM categories of slag, FA, LP, and MK to reduce the amount of cement and SF in UPHC are summarized in this subsection. Here are the summaries of the studies reviewed in this paper. Tables 14-16 summarize the effects of other SCMs on the compressive strength, the flowability, and the shrinkage of UHPC, respectively. 
Table 14. The effect of other SCMs on the compressive strength of UHPC.

\begin{tabular}{|c|c|c|c|c|c|c|}
\hline SCMs & $\begin{array}{l}\text { Compressive } \\
\text { Strength } \\
\text { (MPa @ Age } \\
\text { (\% to the Ref.)) }\end{array}$ & $\begin{array}{l}w / b \\
\text { Ratio }\end{array}$ & Curing Method & $\begin{array}{l}\text { Specimen Size } \\
(\mathrm{mm})\end{array}$ & $\begin{array}{l}\text { Other Solid } \\
\text { Ingredients }\end{array}$ & Ref. \\
\hline RHA $(10 \%)+S F$ & $\begin{array}{c}135 @ 3(10.6 \%) \\
155 @ 7(5.3 \%) \\
185 @ 28(8.8 \%) \\
205 @ 91(4.1 \%)\end{array}$ & 0.18 & Moisture & 40 cube & $\begin{array}{c}\text { Cement (CEM I } 52.5 \\
\text { N), Sand }\end{array}$ & [66] \\
\hline $\mathrm{NP}(\mathbf{1 1 . 8 \% )}+\mathrm{S}$ & $152 @ 28$ (-4.3\%) & 0.15 & Water & 50 cube & $\begin{array}{c}\text { Cement (CEM I), } \\
\text { Sand, Steel fiber (2 } \\
\text { vol. } \%)\end{array}$ & [49] \\
\hline $\mathrm{NP}(24 \%)+\mathrm{SF}$ & $\begin{array}{c}110 @ 7(-11.4 \%) \\
124.5 @ 14(-6.3 \%) \\
130.6 @ 28(-8.7 \%) \\
151 @ 90(-6.6 \%) \\
100 @ 3(-16.7 \%)\end{array}$ & 0.15 & Water & 100 cube & $\begin{array}{c}\text { Cement (CEM I), } \\
\text { Sand, Steel fiber (2 } \\
\text { vol. } \% \text { ) }\end{array}$ & [67] \\
\hline $\begin{array}{l}\text { NMC (1-9\%) } \\
\quad+\text { MK }\end{array}$ & $\begin{array}{c}130 @ 7(-13.3 \%) \\
160 @ 28(-3.0 \%) \\
179 @ 90(6.5 \%)\end{array}$ & 0.20 & Heat & 100 cube & $\begin{array}{l}\text { Cement (CEM I), } \\
\text { Sand, Coarse agg. }\end{array}$ & [68] \\
\hline $\mathrm{DCP}(\leq \mathbf{9} \%)+\mathrm{SF}+\mathrm{LP}$ & $\begin{array}{c}45 @ 3(-0.8 \%) \\
65 @ 7(-0.3 \%) \\
100 @ 28(-0.6 \%)\end{array}$ & 0.18 & Water & $40 \times 40 \times 160$ & $\begin{array}{l}\text { Cement (CEM I 52.5), } \\
\text { Sand }\end{array}$ & [69] \\
\hline $\mathrm{CKD}(4 \%)+\mathrm{SF}$ & $154 @ 28(-5.6 \%)$ & 0.15 & Water & 50 cube & $\begin{array}{c}\text { Cement (CEM I), } \\
\text { Sand, Steel fiber (2 } \\
\text { vol.\%) }\end{array}$ & [49] \\
\hline GGP (11.5\%) +SF & $188 @ 28(15.4 \%)$ & 0.18 & Autoclave & $40 \times 40 \times 160$ & $\begin{array}{l}\text { Cement (CEM I } 42.5 \\
\text { R), Sand, Steel fiber (2 } \\
\text { vol. } \%)\end{array}$ & [70] \\
\hline FGP $(6 \%)+S F$ & $\begin{array}{c}125 @ 7(7.1 \%) \\
175 @ 28(5.0 \%) \\
183 @ 56(4.8 \%) \\
196 @ 91(7.7 \%)\end{array}$ & 0.19 & Sealed & 50 cube & $\begin{array}{l}\text { Cement (CEM HS), } \\
\text { Sand, Quartz powder }\end{array}$ & [71] \\
\hline $\begin{array}{r}\text { BP (14\%) } \\
+\mathrm{SF}+\mathrm{FA}\end{array}$ & $\begin{array}{c}90 @ 7(-16.7 \%) \\
120 @ 28(-1.1 \%) \\
130 @ 56(-10.9 \%)\end{array}$ & 0.16 & Water & $40 \times 40 \times 160$ & $\begin{array}{l}\text { Cement (CEM I), } \\
\text { Sand }\end{array}$ & [59] \\
\hline
\end{tabular}

Table 15. The effect of other SCMs on the flowability of UHPC.

\begin{tabular}{|c|c|c|c|c|c|c|c|c|}
\hline \multirow{2}{*}{ SCMs } & \multicolumn{3}{|c|}{$\begin{array}{c}\text { Flowability } \\
\text { (mm (\% to the Ref.)) }\end{array}$} & \multirow{2}{*}{ w/b Ratio } & \multirow{2}{*}{ SP/b Ratio } & \multirow{2}{*}{$\begin{array}{c}\text { Agg/b } \\
\text { Ratio }\end{array}$} & \multirow{2}{*}{ Type } & \multirow{2}{*}{ Ref. } \\
\hline & Slump Flow & Flow Table & Mini Slump & & & & & \\
\hline $\mathrm{DCP}(9 \%)+\mathrm{SF}+\mathrm{LP}$ & & $\begin{array}{c}255 \\
(-18.9 \%)\end{array}$ & & 0.18 & $3.00 \%$ & 0.90 & Mortar & [69] \\
\hline BP $(\mathbf{1 4} \%)+S F+F A$ & & $\begin{array}{c}230 \\
(58.6 \%)\end{array}$ & & 0.16 & $2.20 \%$ & 0.85 & Mortar & [59] \\
\hline FGP $(6 \%)+S F$ & & & $\begin{array}{c}225 \\
(18.4 \%)\end{array}$ & 0.19 & $1.25 \%$ & 1.13 & Mortar & [71] \\
\hline CKD $(4 \%)+S F$ & & & $\begin{array}{c}220 \\
(-4.3 \%)\end{array}$ & 0.15 & $3.57 \%$ & 0.90 & $\begin{array}{l}\text { Mortar + Steel fiber } \\
\quad(2 \text { vol. } \%)\end{array}$ & [49] \\
\hline GGP (11.5\%) + SF & & $\begin{array}{c}200 \\
(4.2 \%)\end{array}$ & & 0.18 & $1.90 \%$ & 1.18 & $\begin{array}{l}\text { Mortar + Steel fiber } \\
\quad(2 \text { vol. } \%)\end{array}$ & [70] \\
\hline NP $(11.8 \%)+S F$ & & & $\begin{array}{c}195 \\
(-15.2 \%)\end{array}$ & 0.15 & $3.57 \%$ & 0.90 & $\begin{array}{l}\text { Mortar + Steel fiber } \\
\quad(2 \text { vol. } \%)\end{array}$ & [49] \\
\hline $\mathrm{NP}(24 \%)+\mathrm{SF}$ & & $\begin{array}{c}184 \\
(-12.4 \%)\end{array}$ & & 0.15 & $3.57 \%$ & 0.89 & $\begin{array}{l}\text { Mortar + Steel fiber } \\
\quad(2 \text { vol. } \%)\end{array}$ & [67] \\
\hline NMC (1\%) + MK & $\begin{array}{c}155 \\
(-6.6 \%)\end{array}$ & & & 0.20 & $1.00 \%$ & 1.53 & Concrete & [68] \\
\hline
\end{tabular}


Table 16. The effect of other SCMs on the shrinkage of UHPC.

\begin{tabular}{|c|c|c|c|c|c|c|c|c|}
\hline \multirow{2}{*}{ SCMs } & \multicolumn{3}{|c|}{ Shrinkage } & \multirow{2}{*}{ w/b Ratio } & \multicolumn{3}{|c|}{ Binder Weight Ratio } & \multirow{2}{*}{ Ref. } \\
\hline & Auto & Dry & Total & & Cement & SCMs & SF & \\
\hline BP $(\mathbf{1 4} \%)+S F+F A$ & Low & Low & & 0.16 & 0.49 & 0.39 & 0.12 & [59] \\
\hline
\end{tabular}

\subsubsection{Rice Husk Ash (RHA)}

RHA obtained by burning rice husk has a very high specific surface area, higher than $250 \mathrm{~m}^{2} / \mathrm{g}$. The small particle size and the amorphous structure of RHA make it a "highly active pozzolan". Van Tuan et al. indicated that cement hydration can be accelerated by the addition of RHA of which mean particle size is $5.6 \mu \mathrm{m}$, and it can reduce porosity and improve the compressive strength of concretes [66]. The 10\% replacement ratio of cement with RHA can increase compressive strength by $10.6 \%$ and $8.8 \%$ at 3 days and 28 days, respectively. It was also found when the grinding time increases to produce the fine RHA, the pore structure of RHA is gradually collapsed resulting in the lower porosity of RHA. This collapse of RHA can improve the compressive strength of UHPC. It was also found that SF and RHA has a synergic effect on the compressive strength of UHPC; the SF contributes to the early age compressive strength, while RHA to the late age compressive strength.

\subsubsection{Natural Pozzolan (NP)}

$\mathrm{NP}$ obtained from volcanic rocks is a raw material that shows pozzolanic properties so it can lower both costs and $\mathrm{CO}_{2}$ emission of concrete. The content of NP up to $11.8 \%$ of binder in UHPC decreases the compressive strength at 28 days by $4.3 \%$ compared to the reference specimen with SF only [67]. It was found that the replacement of $24 \%$ cement with NP decreases the compressive strength at all ages compared to the reference specimen without NP, but the compressive strength of UHPC is still over $150 \mathrm{MPa}$ at 90 days. NP also decreases the flowability by $15.2 \%$ because of its higher specific surface area $\left(6666 \mathrm{~cm}^{2} / \mathrm{g}\right)$ than that of Portland cement $\left(3700 \mathrm{~cm}^{2} / \mathrm{g}\right)$

\subsubsection{Nano-Metaclay (NMC)}

Norhasri et al. adopted the NMC made from nanoclay which undergoes calcination for $3 \mathrm{~h} \mathrm{[68].} \mathrm{The} \mathrm{particle} \mathrm{size} \mathrm{of} \mathrm{NMC} \mathrm{is} \mathrm{very} \mathrm{small,} \mathrm{as} \mathrm{much} \mathrm{as} 20 \mathrm{~nm}$, which increases the water demand and retards cement hydration. The replacement of the cement of $1 \%$ with NMC decreases the compressive strength by $16.7 \%, 13.3 \%$, and $3.0 \%$ compared to the reference specimen with MK only at 3 days, 7 days, and 28 days, respectively. However, the use of NMC increases the 90 -day compressive strength by $6.5 \%$ because it can fill pores and yield a pozzolanic reaction at late ages. The higher surface area of NMC than that of cement and MK led to decreases in workability; the 1\% inclusion of NMC in the UHPC paste reduces the slump flow of UHPC by $6.6 \%$ compared to the reference specimen.

\subsubsection{Dehydrated Cementitious Powder (DCP)}

DCP can be obtained from recycled construction waste cementitious materials by heating up to $1000^{\circ} \mathrm{C}$. High temperature dehydrates hydrated products such as ettringite, $\mathrm{CSH}$ gel and $\mathrm{Ca}(\mathrm{OH})_{2}$. The dehydrated hydration product will rebuild new hydration products, which are similar to the initial hydration products. Since high temperature is essential to produce DCP from construction wastes, it may not reduce the $\mathrm{CO}_{2}$ emission; however, it can resolve an issue with a large amount of construction wastes. Qian et al. found that the replacement of cement up to $9 \%$ with DCP almost has no significant effect on the compressive strength of UHPC compared to the reference specimen with SF only [69]. However, DCP decreases the flowability by $18.9 \%$ because of the higher water demand caused by its larger specific surface area. It was also observed that the internal unstable 
$\mathrm{CSH}$ structure and the rehydration of $\mathrm{CaO}$ and other substances in DCP consume more water after heating treatment.

\subsubsection{Cement Kiln Dust (CKD)}

Ahmad et al. studied the effect of CKD on the compressive strength of UHPC as a partial substitution of SF [49]. CKD is the fine-grained, solid, and strong alkaline waste removed from cement kiln exhaust gas by air pollution control devices in a cement plant. The content of CKD of up to $4 \%$ of the binder can obtain the compressive strength of over $150 \mathrm{MPa}$ at 28 days but still 5.6\% lower than that of reference specimen with SF. The addition of CKD decreased the mini-slump value by $4.3 \%$ compared to the reference mix. This is attributed to the high $\mathrm{CaO}$ content in CKD up to $49.3 \%$. It is reported that the high $\mathrm{CaO}$ content in CKD increases the water demand.

\subsubsection{Ground Granite Powder (GGP)}

GGP can be obtained from stone processing plants. Since GGP is an industrial waste, it can reduce the cost of UHPC by replacing parts of the SF and cement. The pore structure of the cement matrix is improved mainly because GGP is finer than cement, and it can help fill the pores in the hardened cement matrix. It was found that the replacement of $11.5 \%$ cement with GGP increases the compressive strength by $15.4 \%$ at 28 days than the reference specimen without GGP [70]. Since GGP works as a filler and does not have a pozzolanic reaction in UHPC, the GGP over an optimum amount yielded lower strength. GGP increases the workability of UHPC because GGP lowers the viscosity of the UHPC mortar as it does not react with cementitious material, resulting in increased the flowability by $4.2 \%$ compared to the reference specimen.

\subsubsection{Basalt Stone Powder (BP)}

Yang et al. exploited a BP to reduce the cement amount in UHPC. BP is a type of stone powder obtained from aggregate and its main particle size is around 10-50 $\mu \mathrm{m}$ [59]. The replacement of $14 \%$ cement with BP results in a compressive strength of $16.7 \%, 1.1 \%$, and $10.9 \%$ lower at 7,28 , and 56 days, respectively, compared to the reference specimen with SF and FA only because BP has no chemical effect in cement hydration and only plays a role as filler in UHPC. BP can improve the flowability resulting in a 58.3\% higher flowability than that of the reference specimen. This can be attributed to the dilution effect of the added BP and its lower water absorption. That BP decreases the shrinkage of UHPC was also found. The BP dosage of $14 \%$ to the total binder resulted in lower autogenous and drying shrinkage because the usage of BP reduces the amount of cement in UHPC, and BP can make the microstructure denser so that the surface water evaporates slowly compared to the reference specimen with SF and FA only.

\subsubsection{Fine Glass Powder (FGP)}

Soliman and Tagnit-Hamou found that the use of FGP as a partial substitution of SF can improve both compressive strength and workability [71]. When replacing SF with FGP up to $6 \%$ of the total binder, the 28-day compressive strength of UHPC increases by $5.0 \%$ than the reference specimen with SF only. This is attributed to the pozzolanic reaction from SF and FGP. The use of FGP also increases the workability and when the content of FGP up to $6 \%$ of the binder the slump flow increases by $18.4 \%$ compared to the reference specimen because FGP can decrease the water demand of UHPC with the lower surface area of FGP than that of SF.

RHA and FGP are suitable to improve the compressive strength of UHPC at all ages. The high pozzolanic reactivity of materials resulted in a beneficial effect on the compressive strength. GCP also enhances the compressive strength; however, it works as a filler having no chemical reactions with cement. Other SCMs introduced in this paper degrade the compressive strength, and, therefore, the purpose of their application can be considered as reducing environmental impacts. 


\section{Environmental Evaluation}

The purposes of the usage of SCMs are mainly to reduce material costs and to reduce environmental burdens. Summarizing the comparison of material costs is impractical because the industrial circumstances are different between regions. Therefore, this paper provides a summary of the environmental impact data reviewed in this study.

This paper adopted the embodied carbon dioxide $\left(\mathrm{e}-\mathrm{CO}_{2}\right)$ and energy consumption (e-Energy) data of the raw materials provided by the previous studies [84-86], as shown in Table 17. The embodied $\mathrm{CO}_{2}$ and the embodied energy are based on the carbon footprint per unit $(\mathrm{kg} / \mathrm{kg})$ of each material and the quantity of non-renewable energy per unit $\left(\mathrm{MJ} / \mathrm{kg}\right.$ ) of each raw material, respectively. The embodied $\mathrm{CO}_{2}$ of the UHPC per the unit weight of $1 \mathrm{~kg}$ is calculated as the sum of the values obtained by multiplying the carbon footprint values in Table 17 and the mass ratios of each raw material in Table 18; the calculation method of the e-Energy of UHPC is similar to that of embodied $\mathrm{CO}_{2}$ except using the e-Energy values in Table 17. However, since information is limited in the SCMs of cement, SF, FA, GGBS, MK, and LP, the other SCMs reviewed in Section 3.5 could not be analyzed. The fibers were not taken into account for the calculation because the fiber may dilute the effect of SCMs as not all of the studies applied fibers. Superplasticizers were also not included in the calculation because their dosage in UHPC is relatively very low compared to other ingredients. It is noted that different names of the SCMs are classified to a specific type of SCMs; for example, GGBS, SSP, FGGBS, LTS, SSP, etc. are considered to have the same e- $\mathrm{CO}_{2}$ and e-Energy values as GGBS in Table 17. Additionally, the influence of the curing method on e- $\mathrm{CO}_{2}$ and e-Energy was ignored. Therefore, the data provided in this study have potential errors.

Table 17. The embodied carbon dioxide and energy consumption of the raw materials [84-86].

\begin{tabular}{ccc}
\hline Items & e-CO $\mathbf{2}(\mathbf{k g} / \mathbf{k g})$ & e-Energy (MJ/kg) \\
\hline Cement [85] & 0.8300 & 4.7270 \\
Water [85] & 0.0003 & 0.0060 \\
River sand [85] & 0.0010 & 0.0220 \\
Crushed stone [85] & 0.0070 & 0.1130 \\
Slag [85] & 0.0190 & 1.5880 \\
Fly ash [85] & 0.0090 & 0.8330 \\
Limestone powder [85] & 0.0170 & 0.3500 \\
Metakaolin [85] & 0.4000 & 3.4800 \\
\hline Silica fume [84] & 0.0140 & 0.1000 \\
Sodium silicate [86] & 1.5140 & 18.3000 \\
\hline
\end{tabular}

Table 18. The summary of the e-CO $\mathrm{CO}_{2}$ and the e-Energy of the UHPC reviewed in this study.

\begin{tabular}{|c|c|c|c|c|c|c|c|c|c|c|c|c|c|}
\hline \multirow{2}{*}{ Category } & \multirow{2}{*}{ Binder Mix Design } & \multirow{2}{*}{$\begin{array}{l}\text { Water } \\
\text { (wt. \%) }\end{array}$} & \multicolumn{6}{|c|}{ Binder (wt.\%) } & \multicolumn{2}{|c|}{$\begin{array}{c}\text { Aggregate } \\
\text { (wt. \%) }\end{array}$} & \multirow{2}{*}{$\begin{array}{c}\mathrm{e}-\mathrm{CO}_{2} \\
(\mathrm{~kg} / \mathrm{kg})\end{array}$} & \multirow{2}{*}{$\begin{array}{c}\text { e-Energy } \\
\left(\mathrm{MJ} / \mathrm{m}^{3}\right)\end{array}$} & \multirow{2}{*}{ Ref. } \\
\hline & & & Cement & Slag & FA & $\mathbf{L P}$ & MK & SF & Fine & Coarse & & & \\
\hline \multirow[t]{16}{*}{ Slag } & LTS $(10 \%)+$ SF & 9 & 38 & 5 & 0 & 0 & 0 & 5 & 43 & 0 & 0.321 & 1.906 & [50] \\
\hline & PSS $(4 \%)+\mathrm{MS}$ & 7 & 39 & 2 & 0 & 0 & 0 & 8 & 44 & 0 & 0.324 & 1.885 & [49] \\
\hline & GGBS $(30 \%)$ & 7 & 26 & 11 & 0 & 0 & 0 & 0 & 56 & 0 & 0.218 & 1.415 & [43] \\
\hline & $\operatorname{SSP}(16.9 \%)+\operatorname{SF}$ & 5 & 28 & 7 & 0 & 0 & 0 & 7 & 39 & 13 & 0.239 & 1.487 & [46] \\
\hline & FGGBS $(8.4 \%)+\mathrm{SF}+\mathrm{BA}$ & 8 & 37 & 5 & 9 & 0 & 0 & 5 & 37 & 0 & 0.307 & 1.890 & [40] \\
\hline & $\mathrm{CS}(16 \%)+\mathrm{SF}$ & 7 & 32 & 8 & 0 & 0 & 0 & 10 & 43 & 0 & 0.265 & 1.636 & [51] \\
\hline & GGBS $(23.6 \%)+\mathrm{SF}$ & 7 & 28 & 11 & 0 & 0 & 0 & 8 & 47 & 0 & 0.238 & 1.525 & [45] \\
\hline & GGBS $(20 \%)+$ SF & 7 & 25 & 8 & 0 & 0 & 0 & 8 & 51 & 0 & 0.211 & 1.335 & [44] \\
\hline & $\operatorname{SSP}(15 \%)+\mathrm{LP}+\mathrm{SF}$ & 7 & 25 & 7 & 0 & 9 & 0 & 5 & 46 & 0 & 0.215 & 1.362 & [12] \\
\hline & PS $(35 \%)+\mathrm{SF}$ & 7 & 23 & 16 & 0 & 0 & 0 & 7 & 47 & 0 & 0.199 & 1.382 & [48] \\
\hline & GGBS $(38.5 \%)+$ SF & 8 & 18 & 15 & 0 & 0 & 0 & 5 & 55 & 0 & 0.152 & 1.091 & [42] \\
\hline & FGGBS $(38.5 \%)+$ SF & 8 & 18 & 15 & 0 & 0 & 0 & 5 & 55 & 0 & 0.152 & 1.091 & [42] \\
\hline & GGBS $(30 \%)+\mathrm{SF}$ & 7 & 21 & 14 & 0 & 0 & 0 & 12 & 46 & 0 & 0.178 & 1.228 & [41] \\
\hline & GGBS $(25.5 \%)+\mathrm{SF}+\mathrm{BA}$ & 8 & 21 & 15 & 9 & 0 & 0 & 9 & 38 & 0 & 0.183 & 1.341 & [40] \\
\hline & $\mathrm{PS}(27.4 \%)+\mathrm{SF}+\mathrm{FA}$ & 8 & 22 & 11 & 9 & 0 & 0 & 6 & 44 & 0 & 0.190 & 1.325 & [47] \\
\hline & GGBS $(60 \%)+$ SF & 11 & 16 & 32 & 0 & 0 & 0 & 5 & 37 & 0 & 0.138 & 1.262 & [39] \\
\hline
\end{tabular}


Table 18. Cont.

\begin{tabular}{|c|c|c|c|c|c|c|c|c|c|c|c|c|c|}
\hline \multirow{2}{*}{ Category } & \multirow{2}{*}{ Binder Mix Design } & \multirow{2}{*}{$\begin{array}{l}\text { Water } \\
\text { (wt. \%) }\end{array}$} & \multicolumn{6}{|c|}{ Binder (wt.\%) } & \multicolumn{2}{|c|}{$\begin{array}{l}\text { Aggregate } \\
\text { (wt.\%) }\end{array}$} & \multirow{2}{*}{$\begin{array}{c}\mathrm{e}-\mathrm{CO}_{2} \\
(\mathrm{~kg} / \mathrm{kg})\end{array}$} & \multirow{2}{*}{$\begin{array}{l}\text { e-Energy } \\
\left(\mathrm{MJ} / \mathrm{m}^{3}\right)\end{array}$} & \multirow{2}{*}{ Ref. } \\
\hline & & & Cement & Slag & FA & LP & MK & SF & Fine & Coarse & & & \\
\hline \multirow[t]{10}{*}{ FA } & FA $(38.5 \%)+$ SF & 8 & 18 & 0 & 15 & 0 & 0 & 5 & 55 & 0 & 0.150 & 0.981 & [42] \\
\hline & $\mathrm{BA}(15.7 \%)+\mathrm{SF}$ & 8 & 37 & 0 & 9 & 0 & 0 & 9 & 38 & 0 & 0.306 & 1.821 & [40] \\
\hline & $\mathrm{FA}(12.8 \%)+\mathrm{SF}$ & 8 & 37 & 0 & 7 & 0 & 0 & 9 & 38 & 0 & 0.313 & 1.847 & [40] \\
\hline & FFA $(34.1 \%)+$ SF & 7 & 27 & 0 & 15 & 0 & 0 & 2 & 48 & 0 & 0.228 & 1.425 & [56] \\
\hline & $\mathrm{FA}(20 \%)+\mathrm{SF}$ & 8 & 30 & 0 & 8 & 0 & 0 & 2 & 52 & 0 & 0.250 & 1.496 & [53] \\
\hline & $\mathrm{FA}(20 \%)+\mathrm{MK}(3.8 \%)$ & 17 & 64 & 0 & 17 & 0 & 3 & 0 & 0 & 0 & 0.541 & 3.252 & [55] \\
\hline & $\mathrm{FA}(30 \%)+\mathrm{SF}$ & 8 & 23 & 0 & 10 & 0 & 0 & 0 & 30 & 29 & 0.193 & 1.203 & [52] \\
\hline & $\mathrm{FA}(11.8 \%)+\mathrm{SF}$ & 7 & 39 & 0 & 6 & 0 & 0 & 4 & 44 & 0 & 0.328 & 1.923 & [49] \\
\hline & $\mathrm{FA}(7.4 \%)+\mathrm{GGBS}+\mathrm{SF}$ & 7 & 30 & 4 & 4 & 0 & 0 & 9 & 47 & 0 & 0.250 & 1.520 & [54] \\
\hline & $\mathrm{FA}(15 \%)+\mathrm{SF}$ & 8 & 28 & 0 & 7 & 0 & 0 & 12 & 46 & 0 & 0.233 & 1.391 & {$[41]$} \\
\hline \multirow[t]{5}{*}{ LP } & $\mathrm{LP}(32 \%)+\mathrm{SF}$ & 9 & 39 & 0 & 0 & 22 & 0 & 9 & 21 & 0 & 0.326 & 1.917 & [58] \\
\hline & $\mathrm{NC}(3.2 \%)+\mathrm{SF}$ & 8 & 38 & 0 & 0 & 2 & 0 & 10 & 42 & 0 & 0.318 & 1.823 & [60] \\
\hline & $\mathrm{LP}(37.3 \%)+\mathrm{SF}$ & 10 & 29 & 0 & 0 & 19 & 0 & 3 & 39 & 0 & 0.241 & 1.427 & [57] \\
\hline & $\mathrm{LP}(14 \%)+\mathrm{SF}+\mathrm{FA}$ & 8 & 24 & 0 & 12 & 7 & 0 & 6 & 42 & 0 & 0.206 & 1.297 & [59] \\
\hline & $\mathrm{LP}(4 \%)+\mathrm{SF}$ & 7 & 39 & 0 & 0 & 2 & 0 & 8 & 44 & 0 & 0.327 & 1.874 & [49] \\
\hline \multirow[t]{4}{*}{ MK } & NMK (1\%) + MK & 7 & 33 & 0 & 0 & 0 & 4 & 0 & 20 & 36 & 0.290 & 1.730 & [64] \\
\hline & MK $(20 \%)+$ SF & 9 & 33 & 0 & 0 & 0 & 8 & 0 & 49 & 0 & 0.309 & 1.870 & [61] \\
\hline & MK $(16.7 \%)$ & 8 & 34 & 0 & 0 & 0 & 7 & 0 & 51 & 0 & 0.310 & 1.856 & [63] \\
\hline & $\mathrm{MK}(6.9 \%)+\mathrm{SF}^{(1)}$ & 10 & 0 & 21 & 0 & 0 & 2 & 2 & 50 & 0 & 0.240 & 3.162 & [65] \\
\hline
\end{tabular}

The values of water, solid binder, and aggregate are the mass ratio. (1) The specimen is an alkali-activated material and its mix design was deduced based on the mixing ratio described in the paper. It was assumed that the mass ratio of sodium silicate used is approximately 0.15 , and that the mass ratio of fine aggregate is 0.50 .

The relationship between e- $\mathrm{CO}_{2}$ and e-Energy is almost linear as shown in Figure 1 indicating that the energy used to produce the material also generates $\mathrm{CO}_{2}$ proportionally. Therefore, the e- $\mathrm{CO}_{2}$ data are used to investigate the environmental impact of the UHPC mix designs reviewed in this study. Figure 2 shows the summary of the e- $\mathrm{CO}_{2}$ and the 28-day compressive strength of the UHPCs. The bar graph corresponds to the 28-day compressive strength of the left $Y$-axis and the line plot to the e- $\mathrm{CO}_{2}$ data of the right $Y$-axis, and the hatched ones mean that the specimen was thermally treated. The data are divided by the type of SCMs used and, then, sorted by the 28-day compressive strength in descending order. More detailed information on the e- $\mathrm{CO}_{2}$ and e-Energy can also be found in Table 18. It can be concluded that the 28-day compressive strength of UHPC is not always correlated to the e- $\mathrm{CO}_{2}$ data. This implies the possibilities of optimizing the UHPC mix design for higher compressive strength as well as the lower e- $\mathrm{CO}_{2}$ of UHPC. However, the investigation on the e- $\mathrm{CO}_{2}$ and e-Energy of various types of SCMs should be preceded for the accurate analysis. Slag seems to have a lower environmental impact compared to other SCMs because of its higher dosage. Therefore, the applicable dosage of raw SCM material is also an important factor contributing to the decrease in the e- $\mathrm{CO}_{2}$ of UHPC. It is believed that the summary data can show a comprehensive understanding of which SCMs are more efficient to reduce the environmental impact and to have higher compressive strength. 


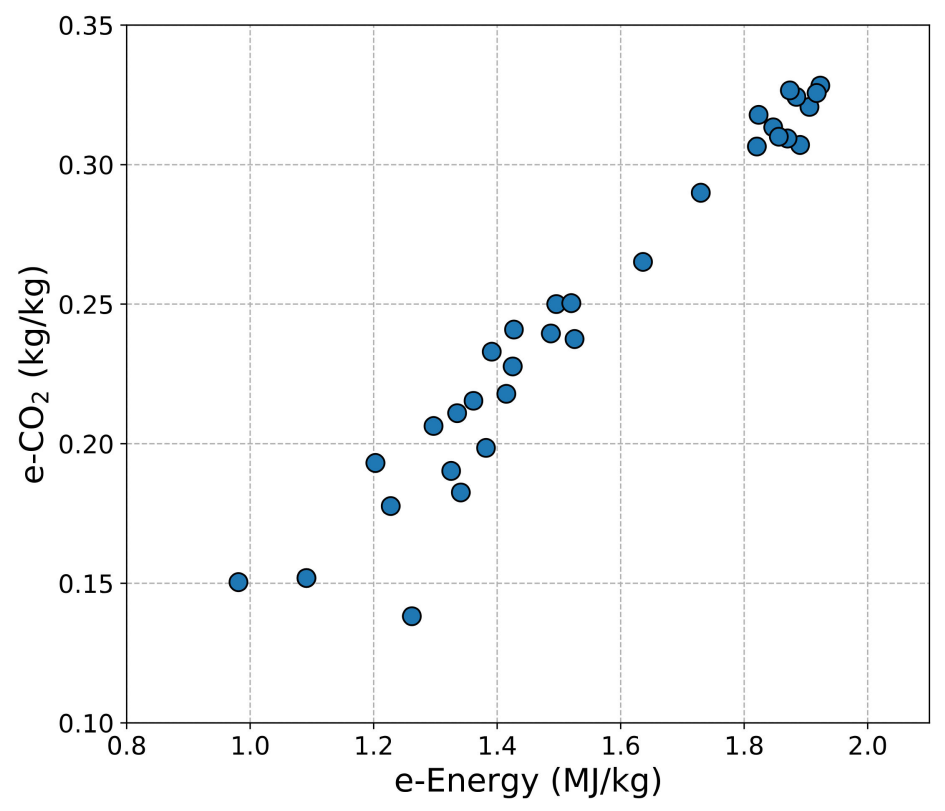

Figure 1. The linear relationship between e- $\mathrm{CO}_{2}$ and e-Energy.

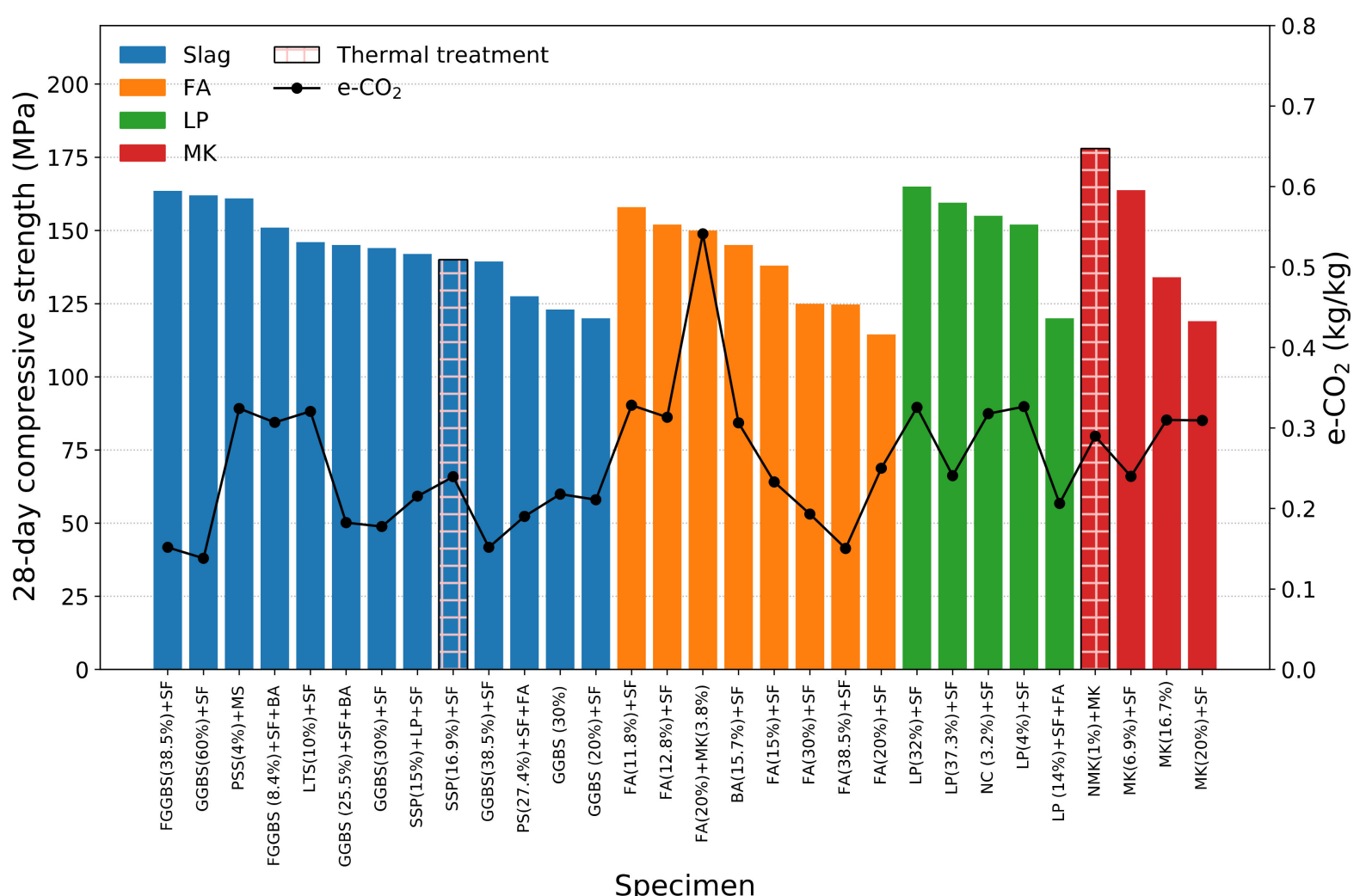

Figure 2. The 28-days compressive strength and the e- $\mathrm{CO}_{2}$ of the UHPC reviewed in this paper.

\section{Conclusions}

This paper reviewed the effect of SCMs on the properties of UHPC. The various types of SCMs such as slag, FA, LP, MK, and others were successfully applied to UHPC, satisfying material requirements such as compressive strength. Based on the discussions, their effects are summarized as follows: 
(1) The main purposes of the usage of SCMs are to decrease the material cost and the environmental impact caused during material production by a partial replacement of cement or silica fume. Since most SCMs are industrial by-products from plants or naturally occurring resources, the usage of SCMs corresponds well to this purpose; it was confirmed that the e- $\mathrm{CO}_{2}$ of UHPC is lower when the dosage of an SCM is higher.

(2) Slag tends to decrease the compressive strength of UHPC at an early age because of the slow hydration of slag, but it increases the late age compressive strength through the pozzolanic reaction between slag and $\mathrm{Ca}(\mathrm{OH})_{2}$ that increases the packing density of the UHPC. The finer particle size of slag exhibits higher compressive strength. Slag also increases the workability of UHPC because of its lower water absorption compared to cement.

(3) FA degrades the compressive strength of UHPC; however, some of the FFA can enhance compressive strength. The ternary use of SCMs including FA can be another feasible option to reduce the amount of cement in UHPC. The effect of FA on the workability of UPHC is different among studies. It is also proved that FA is effective to reduce the shrinkage of UHPC.

(4) LP enhances the compressive strength of UHPC with the three mechanisms: (i) LP decreases the water demand of UHPC, that is, it increases the workability of UHPC, (ii) $\mathrm{LP}$ has a pozzolanic reaction with $\mathrm{SF}$, which increases the late age compressive strength, and (iii) LP can accelerate the cement hydration. However, some cases that LP degrades the compressive strength of UHPC were observed. LP can decrease the shrinkage of UHPC by reducing the amount of cement in UHPC.

(5) MK seems to increase the early age compressive strength of UHPC, but decreases the late age compressive strength. It was confirmed that the MK of the finer particle size can overcome the degradation of the early age compressive strength. It was reported that MK decreases the autogenous shrinkage while it increases the drying shrinkage. Another application of MK was found; the alkali-activated material synthesized using slag, $\mathrm{MK}$, and sodium silicate solution results in the proper compressive strength over $150 \mathrm{MPa}$.

(6) Other SCMs are also introduced. RHA has a synergic effect on the compressive strength of UHPC resulting in the higher compressive strength at both early and late age compared to the reference specimen only with SF. NP decreases the compressive strength of UHPC at all ages; however, it results in the compressive strength of UHPC over $150 \mathrm{MPa}$ at 90 days. NMC increases the late age compressive strength of UHPC because it yields a pozzolanic reaction at late ages. DCP and CDK degrade the compressive strength of UHPC because they increase the water demand. GCP is a good source of SCM; it improves both the compressive strength at 28 days and the flowability of UHPC. GCP does not chemically react in UHPC but works as a filler. $\mathrm{BP}$ was confirmed to decrease the compressive strength of UHPC, but it increases the workability. Partial substitution of SF with FGP can improve both the compressive strength because of its pozzolanic reaction and advance the workability of UHPC because of the lower surface area compared to SF.

Although this paper examined the effect of extensively various SCMs on UHPC properties, the properties themselves are limited in compressive strength, flowability, shrinkage, and environmental impact. Due to the small number of studies found in the literature, other important properties of UHPC such as tensile strength, modulus of elasticity, and fracture energy were not able to be summarized in this paper. Therefore, further studies should be proceeded for a review of the effect of SCMs on those properties.

Author Contributions: Conceptualization, S.P. (Sungwoo Park), S.W., S.P. (Sukhoon Pyo); methodology, S.P. (Sungwoo Park), S.W.; software, S.W.; writing-original draft preparation, S.P. (Sungwoo Park), S.W.; writing-review and editing, Z.L., S.P. (Sukhoon Pyo); visualization, S.P. (Sungwoo Park); supervision, S.P. (Sukhoon Pyo); project administration, S.P. (Sukhoon Pyo); funding acquisition, S.P. (Sukhoon Pyo). All authors have read and agreed to the published version of the manuscript. 
Funding: This work was supported by the National Research Foundation of Korea (NRF) grant funded by the Korean government (MSIT) (No. 2021R1C1C1008671). The opinions expressed in this paper are those of the authors and do not necessarily reflect the views of the sponsors.

Institutional Review Board Statement: Not applicable.

Informed Consent Statement: Not applicable.

Data Availability Statement: The data presented in this study are available on request from the corresponding author.

Conflicts of Interest: The authors declare no conflict of interest.

$\begin{array}{ll}\text { Abbreviations } \\ \text { BA } & \text { Bottom Ash } \\ \text { BP } & \text { Basalt stone Powder } \\ \text { CKD } & \text { Cement Kiln Dust } \\ \text { CS } & \text { Copper Slag } \\ \text { DCP } & \text { Dehydrated Cementitious Powder } \\ \text { FA } & \text { Fly Ash } \\ \text { FFA } & \text { Fine Fly Ash } \\ \text { FGGBS } & \text { Fine Ground Granulated Blast-furnace Slag } \\ \text { FGP } & \text { Fine Glass Powder } \\ \text { GGBS } & \text { Ground Granulated Blast-furnace Slag } \\ \text { GGP } & \text { Ground Granite Powder } \\ \text { LP } & \text { Limestone Powder } \\ \text { LTS } & \text { Lithium Slag } \\ \text { MK } & \text { Metakaolin } \\ \text { NC } & \text { Nano Calcium carbonate } \\ \text { NMC } & \text { Nano Metaclay } \\ \text { NMK } & \text { Nano Metakaolin } \\ \text { NP } & \text { Natural Pozzolan } \\ \text { OPC } & \text { Ordinary Portland Cement } \\ \text { PS } & \text { Phosphorous Slag } \\ \text { PSS } & \text { Pulverized Steel Slag } \\ \text { RHA } & \text { Rice Husk Ash } \\ \text { SF } & \text { Silica Fume } \\ \text { SSP } & \text { Steel Slag Powder }\end{array}$

\section{References}

1. ASTM C1856/M-17. Standars Practice for Fabricating on Testing Specimens of Uhpc; ASTM: West Conshohocken, PA, USA, 2017; pp. 1-8. [CrossRef]

2. Schmidt, M.; Fehling, E. Ultra-high-performance concrete: Research, development and application in Europe. ACI Spec. Publ. 2005, 228, 51-78.

3. Meng, W.; Khayat, K.H.; Bao, Y. Flexural behaviors of fiber-reinforced polymer fabric reinforced ultra-high-performance concrete panels. Cem. Concr. Compos. 2018, 93, 43-53. [CrossRef]

4. Meng, W.; Khayat, K.H. Improving flexural performance of ultra-high-performance concrete by rheology control of suspending mortar. Compos. Part B Eng. 2017, 117, 26-34. [CrossRef]

5. Piérard, J.; Dooms, B.; Cauberg, N. Evaluation of durability parameters of UHPC using accelerated lab tests. In Proceedings of the 3rd International Symposium on UHPC and Nanotechnology for High Performance Construction Materials, Kassel, Germany, 7-9 March 2012; pp. 371-376.

6. Graybeal, B.; Tanesi, J. Durability of an ultrahigh-performance concrete. J. Mater. Civ. Eng. 2007, 19, 848-854. [CrossRef]

7. Pyo, S.; Koh, T.; Tafesse, M.; Kim, H.K. Chloride-induced corrosion of steel fiber near the surface of ultra-high performance concrete and its effect on flexural behavior with various thickness. Constr. Build. Mater. 2019, 224, 206-213. [CrossRef]

8. Piérard, J.; Dooms, B.; Cauberg, N. Durability evaluation of different types of UHPC. In Proceedings of the RILEM-fib-AFGC International Symposium on Ultra-High Performance Fiber-Reinforced Concrete, Marseille, France, 1-3 October 2013; pp. 275-284.

9. Abbas, S.; Soliman, A.M.; Nehdi, M.L. Exploring mechanical and durability properties of ultra-high performance concrete incorporating various steel fiber lengths and dosages. Constr. Build. Mater. 2015, 75, 429-441. [CrossRef] 
10. Pyo, S.; Abate, S.Y.; Kim, H.K. Abrasion resistance of ultra high performance concrete incorporating coarser aggregate. Constr. Build. Mater. 2018, 165, 11-16. [CrossRef]

11. Liu, J.; Song, S.; Wang, L. Durability and micro-structure of reactive powder concrete. J. Wuhan Univ. Technol. Sci. Ed. 2009, 24, 506-509. [CrossRef]

12. Li, S.; Cheng, S.; Mo, L.; Deng, M. Effects of steel slag powder and expansive agent on the properties of ultra-high performance concrete (UHPC): Based on a case study. Materials 2020, 13, 683. [CrossRef]

13. Alkaysi, M.; El-Tawil, S.; Liu, Z.; Hansen, W. Effects of silica powder and cement type on durability of ultra high performance concrete (UHPC). Cem. Concr. Compos. 2016, 66, 47-56. [CrossRef]

14. Pyo, S.; Tafesse, M.; Kim, H.; Kim, H.K. Effect of chloride content on mechanical properties of ultra high performance concrete. Cem. Concr. Compos. 2017, 84, 175-187. [CrossRef]

15. Dils, J.; Boel, V.; De Schutter, G. Influence of cement type and mixing pressure on air content, rheology and mechanical properties of UHPC. Constr. Build. Mater. 2013, 41, 455-463. [CrossRef]

16. Lowke, D.; Stengel, T.; Schießl, P.; Gehlen, C. Control of rheology, strength and fibre bond of UHPC with additions-effect of packing density and addition type. In Ultra-High Performance Concrete and Nanotechnology in Construction, Proceedings of the Hipermat 2012, 3rd International Symposium on UHPC and Nanotechnology for High Performance Construction Materials, Kassel, Germany, 7-9 March 2012; Kassel University Press GmbH: Kassel, Germany, 2012; pp. 215-224.

17. Khayat, K.H.; Meng, W.; Vallurupalli, K.; Teng, L. Rheological properties of ultra-high-performance concrete-An overview. Cem. Concr. Res. 2019, 124, 105828. [CrossRef]

18. Choi, M.S.; Lee, J.S.; Ryu, K.S.; Koh, K.-T.; Kwon, S.H. Estimation of rheological properties of UHPC using mini slump test. Constr. Build. Mater. 2016, 106, 632-639. [CrossRef]

19. Pyo, S.; Wille, K.; El-Tawil, S.; Naaman, A.E. Strain rate dependent properties of ultra high performance fiber reinforced concrete (UHP-FRC) under tension. Cem. Concr. Compos. 2015, 56, 15-24. [CrossRef]

20. Wang, R.; Gao, X.; Huang, H.; Han, G. Influence of rheological properties of cement mortar on steel fiber distribution in UHPC. Constr. Build. Mater. 2017, 144, 65-73. [CrossRef]

21. Wille, K.; El-Tawil, S.; Naaman, A.E. Properties of strain hardening ultra high performance fiber reinforced concrete (UHP-FRC) under direct tensile loading. Cem. Concr. Compos. 2014, 48, 53-66. [CrossRef]

22. Ghafari, E.; Costa, H.; Júlio, E. RSM-based model to predict the performance of self-compacting UHPC reinforced with hybrid steel micro-fibers. Constr. Build. Mater. 2014, 66, 375-383. [CrossRef]

23. Wu, Z.; Shi, C.; He, W.; Wang, D. Static and dynamic compressive properties of ultra-high performance concrete (UHPC) with hybrid steel fiber reinforcements. Cem. Concr. Compos. 2017, 79, 148-157. [CrossRef]

24. Richard, P.; Cheyrezy, M. Reactive Powder Concretes With High Ductility and 200-800 Mpa Compressive Strength. In Concrete Technology: Past, Present, and Future, Proceedings of the V. Mohan Malhotra Symposium ACI SP-144, San Francisco, CA, USA, 21-23 March 1994; American Concrete Institute: Detroit, MI, USA, 1994.

25. Richard, P.; Cheyrezy, M. Composition of reactive powder concretes. Cem. Concr. Res. 1995, 25, 1501-1511. [CrossRef]

26. Kim, H.; Koh, T.; Pyo, S. Enhancing flowability and sustainability of ultra high performance concrete incorporating high replacement levels of industrial slags. Constr. Build. Mater. 2016, 123, 153-160. [CrossRef]

27. Pyo, S.; Kim, H.K.; Lee, B.Y. Effects of coarser fine aggregate on tensile properties of ultra high performance concrete. Cem. Concr. Compos. 2017, 84, 28-35. [CrossRef]

28. Wille, K.; Boisvert-Cotulio, C. Material efficiency in the design of ultra-high performance concrete. Constr. Build. Mater. 2015, 86, 33-43. [CrossRef]

29. Pyo, S.; Tafesse, M.; Kim, B.J.; Kim, H.K. Effects of quartz-based mine tailings on characteristics and leaching behavior of ultra-high performance concrete. Constr. Build. Mater. 2018, 166, 110-117. [CrossRef]

30. Bajaber, M.A.; Hakeem, I.Y. UHPC evolution, development, and utilization in construction: A review. J. Mater. Res. Technol. 2021, 10, 1058-1074. [CrossRef]

31. Xue, J.; Briseghella, B.; Huang, F.; Nuti, C.; Tabatabai, H.; Chen, B. Review of ultra-high performance concrete and its application in bridge engineering. Constr. Build. Mater. 2020, 260, 119844. [CrossRef]

32. Bae, Y.; Pyo, S. Ultra high performance concrete (UHPC) sleeper: Structural design and performance. Eng. Struct. 2020, 210, 110374. [CrossRef]

33. Bae, Y.; Pyo, S. Effect of steel fiber content on structural and electrical properties of ultra high performance concrete (UHPC) sleepers. Eng. Struct. 2020, 222, 111131. [CrossRef]

34. Worrell, E.; Price, L.; Martin, N.; Hendriks, C.; Meida, L.O. Carbon dioxide emissions from the global cement industry. Annu. Rev. Energy Environ. 2001, 26, 303-329. [CrossRef]

35. Odler, I.; Rößler, M. Investigations on the relationship between porosity, structure and strength of hydrated Portland cement pastes. II. Effect of pore structure and of degree of hydration. Cem. Concr. Res. 1985, 15, 401-410. [CrossRef]

36. Rossi, P. Influence of fibre geometry and matrix maturity on the mechanical performance of ultra high-performance cement-based composites. Cem. Concr. Compos. 2013, 37, 246-248. [CrossRef]

37. Yu, R.; Spiesz, P.; Brouwers, H.J.H. Mix design and properties assessment of ultra-high performance fibre reinforced concrete (UHPFRC). Cem. Concr. Res. 2014, 56, 29-39. [CrossRef] 
38. Korpa, A.; Kowald, T.; Trettin, R. Phase development in normal and ultra high performance cementitious systems by quantitative X-ray analysis and thermoanalytical methods. Cem. Concr. Res. 2009, 39, 69-76. [CrossRef]

39. Gupta, S. Development of ultra-high performance concrete incorporating blend of slag and silica fume as cement replacement'. Int. J. Civ. Struct. Eng. Res. 2014, 2, 35-51.

40. Pyo, S.; Kim, H.K. Fresh and hardened properties of ultra-high performance concrete incorporating coal bottom ash and slag powder. Constr. Build. Mater. 2017, 131, 459-466. [CrossRef]

41. Wu, Z.; Shi, C.; He, W. Comparative study on flexural properties of ultra-high performance concrete with supplementary cementitious materials under different curing regimes. Constr. Build. Mater. 2017, 136, 307-313. [CrossRef]

42. Randl, N.; Steiner, T.; Ofner, S.; Baumgartner, E.; Mészöly, T. Development of UHPC mixtures from an ecological point of view. Constr. Build. Mater. 2014, 67, 373-378. [CrossRef]

43. Yu, R.; Spiesz, P.; Brouwers, H.J.H. Development of an eco-friendly Ultra-High Performance Concrete (UHPC) with efficient cement and mineral admixtures uses. Cem. Concr. Compos. 2015, 55, 383-394. [CrossRef]

44. Liu, Z.; El-Tawil, S.; Hansen, W.; Wang, F. Effect of slag cement on the properties of ultra-high performance concrete. Constr. Build. Mater. 2018, 190, 830-837. [CrossRef]

45. Abdulkareem, O.M.; Ben Fraj, A.; Bouasker, M.; Khelidj, A. Mixture design and early age investigations of more sustainable UHPC. Constr. Build. Mater. 2018, 163, 235-246. [CrossRef]

46. Liu, J.; Guo, R. Applications of Steel Slag Powder and Steel Slag Aggregate in Ultra-High Performance Concrete. Adv. Civ. Eng. 2018, 2018, 1-8. [CrossRef]

47. Yang, R.; Yu, R.; Shui, Z.; Gao, X.; Xiao, X.; Zhang, X.; Wang, Y.; He, Y. Low carbon design of an Ultra-High Performance Concrete (UHPC) incorporating phosphorous slag. J. Clean. Prod. 2019, 240, 118157. [CrossRef]

48. Peng, Y.Z.; Huang, J.; Ke, J. Preparation of Ultra-High Performance Concrete Using Phosphorous Slag Powder. Appl. Mech. Mater. 2013, 357-360, 588-591. [CrossRef]

49. Ahmad, S.; Hakeem, I.; Maslehuddin, M. Development of UHPC Mixtures Utilizing Natural and Industrial Waste Materials as Partial Replacements of Silica Fume and Sand. Sci. World J. 2014, 2014, 713531. [CrossRef] [PubMed]

50. He, Z.; Du, S.; Chen, D. Microstructure of ultra high performance concrete containing lithium slag. J. Hazard. Mater. 2018, 353, 35-43. [CrossRef]

51. Edwin, R.S.; De Schepper, M.; Gruyaert, E.; De Belie, N. Effect of secondary copper slag as cementitious material in ultra-high performance mortar. Constr. Build. Mater. 2016, 119, 31-44. [CrossRef]

52. Šeps, K.; Broukalová, I.; Chylík, R. Cement Substitutions in UHPC and their Influence on Principal Mechanical-Physical Properties. IOP Conf. Ser. Mater. Sci. Eng. 2019, 522, 012009. [CrossRef]

53. Alsalman, A.; Dang, C.N.; Micah Hale, W. Development of ultra-high performance concrete with locally available materials. Constr. Build. Mater. 2017, 133, 135-145. [CrossRef]

54. Yazıcı, H.; Yiğiter, H.; Karabulut, A.Ş.; Baradan, B. Utilization of fly ash and ground granulated blast furnace slag as an alternative silica source in reactive powder concrete. Fuel 2008, 87, 2401-2407. [CrossRef]

55. Li, Z. Drying shrinkage prediction of paste containing meta-kaolin and ultrafine fly ash for developing ultra-high performance concrete. Mater. Today Commun. 2016, 6, 74-80. [CrossRef]

56. Ferdosian, I.; Camões, A. Eco-efficient ultra-high performance concrete development by means of response surface methodology. Cem. Concr. Compos. 2017, 84, 146-156. [CrossRef]

57. Li, P.P.; Brouwers, H.J.H.; Chen, W.; Yu, Q. Optimization and characterization of high-volume limestone powder in sustainable ultra-high performance concrete. Constr. Build. Mater. 2020, 242, 118112. [CrossRef]

58. Huang, W.; Kazemi-Kamyab, H.; Sun, W.; Scrivener, K. Effect of cement substitution by limestone on the hydration and microstructural development of ultra-high performance concrete (UHPC). Cem. Concr. Compos. 2017, 77, 86-101. [CrossRef]

59. Yang, R.; Yu, R.; Shui, Z.; Gao, X.; Han, J.; Lin, G.; Qian, D.; Liu, Z.; He, Y. Environmental and economical friendly ultra-high performance-concrete incorporating appropriate quarry-stone powders. J. Clean. Prod. 2020, 260, 121112. [CrossRef]

60. Wu, Z.; Shi, C.; Khayat, K.H.; Xie, L. Effect of SCM and nano-particles on static and dynamic mechanical properties of UHPC. Constr. Build. Mater. 2018, 182, 118-125. [CrossRef]

61. Tafraoui, A.; Escadeillas, G.; Lebaili, S.; Vidal, T. Metakaolin in the formulation of UHPC. Constr. Build. Mater. 2009, 23, 669-674. [CrossRef]

62. Tafraoui, A.; Escadeillas, G.; Vidal, T. Durability of the Ultra High Performances Concrete containing metakaolin. Constr. Build. Mater. 2016, 112, 980-987. [CrossRef]

63. Li, Z.; Rangaraju, P.R. Development of UHPC using a ternary blend of ultra. In International Interactive Symposium on Ultra-High Performance Concrete;-Fine Class F Fly Ash, Meta-Kaolin and Portland Cement; Iowa State University Digital Press: Ames, IA, USA, 2016.

64. Muhd Norhasri, M.S.; Hamidah, M.S.; Mohd Fadzil, A.; Megawati, O. Inclusion of nano metakaolin as additive in ultra high performance concrete (UHPC). Constr. Build. Mater. 2016, 127, 167-175. [CrossRef]

65. Wetzel, A.; Middendorf, B. Influence of silica fume on properties of fresh and hardened ultra-high performance concrete based on alkali-activated slag. Cem. Concr. Compos. 2019, 100, 53-59. [CrossRef]

66. Van Tuan, N.; Ye, G.; Van Breugel, K.; Fraaij, A.L.A.; Bui, D.D. The study of using rice husk ash to produce ultra high performance concrete. Constr. Build. Mater. 2011, 25, 2030-2035. [CrossRef] 
67. Ahmad, S.; Mohaisen, K.O.; Adekunle, S.K.; Al-Dulaijan, S.U.; Maslehuddin, M. Influence of admixing natural pozzolan as partial replacement of cement and microsilica in UHPC mixtures. Constr. Build. Mater. 2019, 198, 437-444. [CrossRef]

68. Norhasri, M.S.M.; Hamidah, M.S.; Fadzil, A.M. Inclusion of nano metaclayed as additive in ultra high performance concrete (UHPC). Constr. Build. Mater. 2019, 201, 590-598. [CrossRef]

69. Qian, D.; Yu, R.; Shui, Z.; Sun, Y.; Jiang, C.; Zhou, F.; Ding, M.; Tong, X.; He, Y. A novel development of green ultra-high performance concrete (UHPC) based on appropriate application of recycled cementitious material. J. Clean. Prod. 2020, 261, 121231. [CrossRef]

70. Zhang, H.; Ji, T.; He, B.; He, L. Performance of ultra-high performance concrete (UHPC) with cement partially replaced by ground granite powder (GGP) under different curing conditions. Constr. Build. Mater. 2019, 213, 469-482. [CrossRef]

71. Soliman, N.A.; Tagnit-Hamou, A. Partial substitution of silica fume with fine glass powder in UHPC: Filling the micro gap. Constr. Build. Mater. 2017, 139, 374-383. [CrossRef]

72. Oner, A.; Akyuz, S. An experimental study on optimum usage of GGBS for the compressive strength of concrete. Cem. Concr. Compos. 2007, 29, 505-514. [CrossRef]

73. Regourd, M.; Thomassin, J.H.; Baillif, P.; Touray, J.C. Blast-furnace slag hydration. Surface analysis. Cem. Concr. Res. 1983, 13, 549-556. [CrossRef]

74. Manmohan, D.; Mehta, P.K. Influence of pozzolanic, slag, and chemical admixtures on pore size distribution and permeability of hardened cement pastes. Cem. Concr. Aggregates 1981, 3, 63-67.

75. Thomassin, J.H.; Goni, J.; Baillif, P.; Touray, J.C.; Jaurand, M.C. An XPS study of the dissolution kinetics of chrysotile in 0.1 N oxalic acid at different temperatures. Phys. Chem. Miner. 1977, 1, 385-398. [CrossRef]

76. Liu, Z.; Hansen, W. Aggregate and slag cement effects on autogenous shrinkage in cementitious materials. Constr. Build. Mater. 2016, 121, 429-436. [CrossRef]

77. Chern, J.-C.; Chan, Y.-W. Deformations of concretes made with blast-furnace slag cement and ordinary portland cement. Mater. J. 1989, 86, 372-382.

78. Darquennes, A.; Staquet, S.; Delplancke-Ogletree, M.-P.; Espion, B. Effect of autogenous deformation on the cracking risk of slag cement concretes. Cem. Concr. Compos. 2011, 33, 368-379. [CrossRef]

79. Virgalitte, S.J.; Luther, M.D.; Rose, J.H.; Mather, B.; Bell, L.W.; Ehmke, B.A.; Klieger, P.; Roy, D.M.; Call, B.M.; Hooton, R.D.; et al. Ground Granulated Blast-Furnace Slag as a Cementitious Constituent in Concrete; American Concrete Institute ACI Report 233R-95; American Concrete Institute: Farmington Hills, MI, USA, 1995.

80. Bonavetti, V.; Donza, H.; Menéndez, G.; Cabrera, O.; Irassar, E.F. Limestone filler cement in low w/c concrete: A rational use of energy. Cem. Concr. Res. 2003, 33, 865-871. [CrossRef]

81. Bakera, A.T.; Alexander, M.G. Use of metakaolin as supplementary cementitious material in concrete, with focus on durability properties. RILEM Tech. Lett. 2019, 4, 89-102. [CrossRef]

82. Vejmelková, E.; Pavlíková, M.; Keppert, M.; Keršner, Z.; Rovnaníková, P.; Ondráček, M.; Sedlmajer, M.; Černý, R. High performance concrete with Czech metakaolin: Experimental analysis of strength, toughness and durability characteristics. Constr. Build. Mater. 2010, 24, 1404-1411. [CrossRef]

83. Ramezanianpour, A.A.; Bahrami Jovein, H. Influence of metakaolin as supplementary cementing material on strength and durability of concretes. Constr. Build. Mater. 2012, 30, 470-479. [CrossRef]

84. Kuruşcu, A.O.; Girgin, Z.C. Efficiency of Structural Materials in Sustainable Design. J. Civ. Eng. Archit. 2014, 8.

85. Long, G.; Gao, Y.; Xie, Y. Designing more sustainable and greener self-compacting concrete. Constr. Build. Mater. 2015, 84, 301-306. [CrossRef]

86. Turner, L.K.; Collins, F.G. Carbon dioxide equivalent (CO2-e) emissions: A comparison between geopolymer and OPC cement concrete. Constr. Build. Mater. 2013, 43, 125-130. [CrossRef] 